\title{
Finland: European Integration and International Human Rights Treaties as Sources of Domestic Constitutional Change and Dynamism
}

\author{
Tuomas Ojanen and Janne Salminen
}

\begin{abstract}
The Constitution Act of 1919 was replaced in 2000 by a new Constitution, which was amended in 2012. While the institution of exceptive enactments, which enables the adoption of laws that are in conflict with the Constitution, had earlier assumed a key role in constitutional adjustment for EU integration, the 2012 amendments expressed a constitutional commitment to EU membership and provided for the transfer of powers to the EU. As a result, exceptive enactments are no longer needed for such transfer. Instead of a constitutional court, a key role in constitutional review is played by the Constitutional Law Committee of Parliament through ex ante review of legislative proposals or other matters pending before Parliament, including proposals for EU legislation, for their compatibility with the Constitution and Finland's international human rights obligations. From the late 1980 s onwards, the constitutional tendency has increasingly been towards rights-based judicial review. Aside from the ECHR and other human rights treaties, EU membership has greatly contributed to both judicial empowerment and enhanced rights protection. Areas where EU law has presented constitutional challenges include: (a) the European Arrest Warrant, with regard to which Finland introduced constitutional and legislative safeguards for the sake of fundamental rights; (b) the Laval and Viking Line stream of case law; and (c) concerns around preserving 'the quality of law' when implementing EU law. In result of the ex ante constitutional review of the draft ESM Treaty, a change in the
\end{abstract}

Tuomas Ojanen is Professor of Constitutional Law, University of Helsinki. e-mail: tuomas. ojanen@helsinki.fi.

Janne Salminen is Professor of Public Law, University of Turku. e-mail: janne.salminen@utu.fi. All websites accessed 26 October 2015. Text submitted 29 May 2015.

\footnotetext{
T. Ojanen $(\bowtie)$

University of Helsinki, Helsinki, Finland

e-mail: tuomas.ojanen@helsinki.fi

J. Salminen

University of Turku, Turku, Finland

e-mail: janne.salminen@utu.fi

(C) The Author(s) 2019

A. Albi and S. Bardutzky (eds.), National Constitutions in European

and Global Governance: Democracy, Rights, the Rule of Law,

https://doi.org/10.1007/978-94-6265-273-6_9
} 
draft treaty stemming from constitutional concerns about increased financial liabilities without parliamentary control was proposed and achieved.

Keywords The Constitution of Finland of 2000 - The 2012 amendment of the Constitution in relation to EU and international co-operation $\cdot$ Ex ante constitutional review by the Constitutional Committee of Parliament $\cdot$ Fundamental rights and the rule of law - Rise of rights-based judicial review - Constitutional and legislative safeguards with regard to the European Arrest Warrant and extraditions Data Retention Directive - Laval, Viking Line, posted workers and collective action Quality of law - Parliamentary reservation of law when implementing EU and international measures • ESM Treaty and maximum financial liabilities Article 53 EU Charter and the question of a higher standard of protection

\section{Constitutional Amendments Regarding EU Membership}

\subsection{Introduction: Some Characteristics of the Finnish Constitutional System and Culture}

1.1.1-1.1.2 The Constitution, as a legal and political instrument, has traditionally been highly esteemed in Finland. The origins of great respect for constitutional enactments can be traced as far back as the legal-positivist resistance by the Finnish legal and political elite to the campaigns of 'Russification' between 1899 and 1905 . Over a century, from 1809 to 1917, Finland was an autonomous Grand Duchy within the Russian Empire and thus had its own legal system, including constitutional enactments inherited from the era of Swedish rule (before 1809). During the years of 'Russification', however, Finns fought against arbitrary Russian interferences in Finland's domestic legal and political affairs by advancing a constitutional challenge, essentially founded on a simple, yet firm claim that all authorities, including those of the Russian Empire, had to strictly observe Finland's constitutional enactments and Finnish law in general in the exercise of their powers. As this constitutional challenge also proved very successful, a strong tradition of legalism, including respect for the rule of law, began to characterise Finnish constitutionalism from those years onwards. ${ }^{1}$

The current Constitution of Finland (Act No. 731/1999) ${ }^{2}$ entered into force on 1 March 2000, and replaced the earlier Constitution Act of 1919 and three other

\footnotetext{
${ }^{1}$ See in more detail Ojanen 2007, pp. 146-148. See about the Finnish understanding of the Constitution and the legacy of autonomy under the Russian Empire, also Mutanen 2015, pp. 272 276 with references.

${ }^{2}$ All translations are from the unofficial translation of the Constitution of Finland, including amendments up to 1112/2011, in English available at: https://www.finlex.fi/fi/laki/kaannokset/ 1999/en19990731.pdf.
} 
enactments enjoying constitutional status. ${ }^{3}$ The Constitution of Finland is a modern and unified constitutional document with a concise and uniform style. Aside from including some new elements and codifying certain practices and doctrines, the Constitution of Finland incorporates a number of principles, structures and solutions that were already established in earlier constitutional documents. As with earlier constitutional enactments, the Constitution can be understood as enjoying strong legitimacy across the whole sweep of the Finnish political system and society, as Parliament adopted the Constitution almost unanimously, with a final vote of 175 for and only 2 against.

For the practical and theoretical purposes of this paper, the following two peculiarities of the Finnish constitutional system are particularly worthy of elaboration. The first constitutional idiosyncrasy is the structural framework of the Finnish model of constitutional review. It still primarily assumes the nature of (abstract) ex ante review by the Constitutional Law Committee of Parliament of legislative proposals and other matters brought for its consideration for their relation to the Constitution and international human rights treaties. ${ }^{4,5}$ By contrast, Finland has always lacked a distinct constitutional court. Moreover, there was a rigid prohibition of judicial review of Acts of Parliament for their compatibility with the Constitution until the entry into force of the current Constitution of Finland in 2000. Although Sect. $106^{6}$ of the Constitution now empowers courts to give primacy to the Constitution if the application of an Act of Parliament would be in 'manifest conflict' with the Constitution, Sect. 106 amounts to a form of weak judicial review that combines the abstract ex ante constitutional review of legislation by the Constitutional Law Committee of Parliament with the concrete ex post judicial review by the courts. In this model, the ex ante constitutional review by the Constitutional Law Committee is still supposed to remain the primary form of review, whereas judicial review under Sect. 106 is designed to plug loopholes left in the abstract ex ante review of the constitutionality of government bills, inasmuch as unforeseen constitutional problems might arise in applying the law by the courts in particular cases.

The main difference in comparison with constitutional courts is, of course, that in the Finnish model the power of review is held by a primarily political organ

\footnotetext{
${ }^{3}$ Accordingly, there were four constitutional enactments enjoying constitutional status: the Constitution Act of Finland, the Parliament Act and two Acts on ministerial liability. All Acts were passed during the first years of independence (the Acts of 94/1919; 7/1928; 274/1922; and 273/ 1922).

${ }^{4}$ Section 74 of the Constitution, entitled 'Supervision of constitutionality', provides as follows: 'The Constitutional Law Committee shall issue statements on the constitutionality of legislative proposals and other matters brought for its consideration, as well as on their relation to international human rights treaties.'

${ }^{5}$ For the Finnish system of constitutional review, see Lavapuro et al. 2011, pp. 505-531.

${ }^{6}$ Section 106 of the 2000 Constitution, entitled 'The Primacy of the Constitution', provides as follows: 'If in a matter being tried by a court, the application of an Act of Parliament would be in manifest conflict with the Constitution, the court of law shall give primacy to the provision in the Constitution.' For the background of Sect. 106, see Ojanen 2009a.
} 
composed of Members of Parliament and acting as an integral part in the political process of legislative action. A cautionary note for those readers who believe that the political organisation of constitutional review automatically results in a non-legalistic and morally deep deliberation of rights issues. Despite its political organisation, the practice of the Finnish Constitutional Law Committee is characterised by formalistic argumentation and a search for interpretations that can be directly linked to the text of the Constitution or its preparatory works as well as to its own precedents. Moreover, before issuing its Opinions or Reports, the Committee regularly hears experts in constitutional law, notably university professors, whose opinions have significant impact on the Committee's interpretive framework. While not formally legally binding, the statements by the Committee on the harmony or discrepancy of a bill with the Constitution are generally treated as authoritative. It is quite usual for the Committee to find a bill to be unconstitutional in one or more respects and, accordingly, require amendments to be made to the bill during its parliamentary consideration.

Given that the Constitutional Law Committee of Parliament assumes a role similar to the usual role of a constitutional court in centralised forms of constitutional review, the practice of the Committee will be of great significance for the purposes of this report.

The second traditional distinction, even quirk, of the Finnish constitutional system is the institution of exceptive enactments. ${ }^{7}$ The origins of this institution can be traced as far back as the era of the Grand Duchy of Finland in the Russian Empire between 1809 and 1917. In essence, this institution makes it possible to adopt laws that in substance conflict with the Constitution without amending the text thereof, subject to the proviso, however, that such exceptive enactments be approved in accordance with the procedure for constitutional enactments. Traditionally, constitutional lawyers speak about making a 'hole' in the Constitution by an exceptive enactment and filling it with the relevant norms of the exceptive enactment.

While the importance of the institution of exceptive enactments has gradually decreased since the late 1980s and the Constitution of Finland now also imposes limits to derogations from the Constitution by means of exceptive enactments, the institution of exceptive enactments has assumed a significant role in the context of EU membership, as will be discussed in more detail below in Sect. 1.2.1.

The third most significant characteristic of the contemporary constitutional system, including constitutional culture, relates to the domestic system of the protection of fundamental and human rights. Up until the late 1980s, fundamental and human rights, as well as their judicial safeguards, assumed a marginal role on the Finnish scene of constitutionalism. As the Finnish Constitution subscribed to the French Revolutionary conception of the law as a supreme expression of the

\footnotetext{
${ }^{7}$ A brief historical review of this institution in English is provided in Scheinin 2002, pp. 55 and 56.
} 
people's will as well as to ideas about democracy as majority rule, ${ }^{8}$ the outcome was a rigid prohibition of judicial review and a marginal role for individual rights, although the Finnish Constitution has included a distinct catalogue of constitutional rights ever since the entry into force of the Constitution Act of 1919.

Since the late 1980s, however, tendencies of Europeanisation, rights-based judicial review and the rise of international organisations and global institutions with their regulatory networks have entailed that fundamental rights and human rights treaties binding on Finland have started to play a greater role in the courts and the Finnish scene of constitutionalism in general. ${ }^{9}$ In particular, Finland's accession to the European Convention on Human Rights (ECHR) in 1989 and the incorporation of its provisions into the domestic legal order in 1990 represents one of the most important turns in Finnish constitutional history. ${ }^{10}$ Human rights treaties binding on Finland, with the ECHR at their apex, provided the main inspiration and stimulus for a comprehensive reform of the domestic system for the protection of constitutional rights, which entered into force on 1 August 1995. As a result of the reform, the current fundamental rights catalogue in the 1999 Constitution of Finland (Chap. 2 of the Constitution) is very comprehensive, setting out a range of economic, social, cultural and 'third-generation' rights alongside more traditional civil and political rights. ${ }^{11}$ Moreover, these transformations of the Finnish constitutional system and culture regarding fundamental and human rights have been accompanied by a tendency towards stronger judicial safeguards for rights protection, although the growing role of the judiciary also owes to such tendencies of modern law as an overflow of legislation and open-ended framework legislation that pass important decision-making power to the level of concrete cases. In addition, EU membership has greatly contributed to a shift of competence to the judiciary.

\subsection{The Amendment of the Constitution of Finland in Relation to the European Union}

1.2.1 European Union related amendments On the threshold of EU membership, the Constitution assumed a very minimalist approach to integration and internationalisation in general. The Constitution was very introverted and domestic-oriented. ${ }^{12}$ The Constitution lacked a constitutional provision permitting limitations of sovereignty or the transfer of powers to international organisations, not to speak of the EU in particular.

\footnotetext{
8 See Nergelius 2006.

${ }^{9}$ Lavapuro et al. 2011.

${ }^{10}$ See also Viljanen 1996.

11 See also Salminen 2014, pp. 41-63, and Ojanen 2013, pp. 93-113.

12 Ojanen 2013, p. 110.
} 
Due to the availability of the institution of exceptive enactments, no amendment of the Constitution was found necessary to enable Finland to join the EU despite the fact that the Accession Treaty was deemed to be in conflict with the Constitution, with the major reason simply being the incompatibility of the Accession Treaty with the sovereignty of Finland. ${ }^{13}$ Accordingly, the Treaty of Accession was incorporated into Finnish law through an exceptive enactment (Act No. 1540 of 1994), approved by a two-thirds majority in Parliament.

However, some changes in the Constitution Act of 1919 were found necessary; the relevant amendments concerned the domestic distribution of powers between the Government and the President, and the role of Parliament in EU affairs. ${ }^{14}$ The accession of Finland to the European Economic Area (EEA) in 1994 and to the EU in 1995 had already increased pressure to reconsider the domestic distribution of powers between Parliament, the Government and the President. Although the powers of the President had already been reduced in domestic affairs, the President still enjoyed strong powers in the sphere of foreign affairs in the early 1990s. Thus, one of the most important issues to be decided in Finland prior to embarking on the process of European integration was whether European affairs - first EEA affairs and later EU affairs - should be considered as domestic or foreign policy matters. In the latter case, they would have fallen within the competence of the President by virtue of Sect. 33 of the Constitution Act of 1919, with the outcome that the constitutional pendulum would have lurched back again towards a strong presidency, thereby watering down constitutional amendments since the early 1980s that nudged the Finnish constitutional system towards parliamentarism. In particular, this outcome would have meant a severe blow to the participation of Parliament in EU affairs.

However, the competences were arranged according to the same ratio used in domestic legislative affairs, instead of the typical competence arrangements for foreign policy. Accordingly, the Constitution was amended so that the main responsibility for the national preparation of EEA affairs and later EU affairs was given to the Government, whose members are individually and collectively accountable to Parliament. This was important because the line of development had since the mid-1980s begun to move towards parliamentarism from the previous strong powers of the President, and EU membership and these arrangements gave support to this tendency. EU membership resulted in a horizontal relocation of authority between Parliament, the Government and the President, and contributed to an enhancement of the parliamentary features of the Finnish constitutional-political system. In addition, specific constitutional provisions were enacted for the purpose of ensuring the participation of Parliament in considering EU affairs, which would,

\footnotetext{
${ }^{13}$ See Opinion 14/1994 of the Constitutional Law Committee of Parliament.

${ }^{14}$ See also Ojanen 2004, pp. 536-538 and 551-554. See generally Salminen 2015, discussing the changes as transformations of the integration norms of the Finnish Constitution. See also Mutanen 2015 , discussing the changes in the concept of sovereignty in Finland from a comparative perspective. Mutanen 2015 provides a detailed account of the amendment process, drafting history and relevant literature in English.
} 
according to the Constitution, otherwise fall within the competence of Parliament. In the same wave, Parliament was also given strong rights for receiving information in EU affairs. ${ }^{15}$

In the Finnish context the experiences of this system - the allocation of powers and the strong participation and information rights of Parliament - were considered to be so valuable that the same provisions were adopted in the Constitution of 2000 .

\section{Section 96}

The Parliament considers those proposals for acts, agreements and other measures which are to be decided in the European Union and which otherwise, according to the Constitution, would fall within the competence of the Parliament.

The Government shall, for the determination of the position of the Parliament, communicate a proposal referred to in paragraph (1) to the Parliament by a communication of the Government, without delay, after receiving notice of the proposal. The proposal is considered in the Grand Committee and ordinarily in one or more of the other Committees that issue statements to the Grand Committee. However, the Foreign Affairs Committee considers a proposal pertaining to foreign and security policy. Where necessary, the Grand Committee or the Foreign Affairs Committee may issue to the Government a statement on the proposal. In addition, the Speaker's Council may decide that the matter be taken up for debate in plenary session, during which, however, no decision is made by the Parliament.

The Government shall provide the appropriate Committees with information on the consideration of the matter in the European Union. The Grand Committee or the Foreign Affairs Committee shall also be informed of the position of the Government on the matter.

\section{Section 97}

The Foreign Affairs Committee of the Parliament shall receive from the Government, upon request and when otherwise necessary, reports of matters pertaining to foreign and security policy. Correspondingly, the Grand Committee of the Parliament shall receive reports on the preparation of other matters in the European Union. The Speaker's Council may decide on a report being taken up for debate in plenary session, during which, however, no decision is made by the Parliament.

The Prime Minister shall provide the Parliament or a Committee with information on matters to be dealt with in a European Council beforehand and without delay after a meeting of the Council. The same applies when amendments are being prepared to the treaties establishing the European Union.

The appropriate Committee of the Parliament may issue a statement to the Government on the basis of the reports or information referred to above.

Powers are distributed between the Government and the President such that Government clearly has the general competence for EU affairs. According to Sect. 93(2)

[t]he Government is responsible for the national preparation of the decisions to be made in the European Union, and decides on the concomitant Finnish measures, unless the decision requires the approval of the Parliament. The Parliament participates in the national preparation of decisions to be made in the European Union, as provided in this Constitution.

\footnotetext{
${ }^{15}$ See also Ojanen 2004, pp. 554-557, and Viljanen 2003.
} 
Further, the Constitution of Finland of 2000, which of course was enacted when Finland was an EU member and as such was designed to function as a constitution of a Member State, ${ }^{16}$ tried to codify the new doctrinal transitions which had occurred in the understanding of Finnish sovereignty by including a so-called internationalisation principle (Sect. 1(3)) according to which

Finland participates in international co-operation for the protection of peace and human rights and for the development of society.

According to the travaux préparatoires, this provision functions to offer a new dimension for the construction of sovereignty so that those international obligations which are deemed to be 'conventional' in modern international co-operation and which only affect sovereignty in a 'minor way' will no longer be deemed to conflict with the sovereignty of Finland. Moreover, the sovereignty doctrine is based on the idea of the specificity of the EU, with greater tolerance of the limitations on sovereignty stemming from EU membership than those derived from other international obligations. In particular, the part of the section referring to the 'development of society' was meant to denote EU membership.

Nevertheless, membership in the EU was not very visible in the Constitution. Yet one can also not claim that membership was not explicitly reflected in the wording of the Constitution because the provisions on division of powers between state organs included sections on the EU. From the very start of Finland's EU membership, there has been debate over the question to what extent, if any, EU membership should be recognised in the text of the Constitution. Even the entry into force of the Constitution of Finland in 2000 failed to answer this question in a satisfactory way, as it did not contain any explicit references to the EU. The most problematic issue was, however, that the Constitution lacked a solid way of transferring the powers of the state. Upon incorporating the Constitutional Treaty and Lisbon Treaty into Finnish law it became obvious that the transfers could no longer be based on exceptive enactments. Moreover, the fact that EU membership was not clearly stated as part of the fundamental organisation of Finland was considered problematic. ${ }^{17}$

Thus, when the Constitution and its functioning were evaluated and amended after having been in force for ten years, these issues were revisited in a new light. After the amendments of 2012, the Constitution now reflects the constitutional orientation towards international cooperation for societal development through the EU and expresses commitment to EU membership. In a way, the infancy of EU membership is now over and the Constitution has grown up to be able to face the EU. This new approach can also be observed in new provisions explicitly providing that a significant transfer of state powers to the EU or an international organisation requires a decision made by at least two-thirds of the votes cast in Parliament. This also means that transfers of 'insignificant' powers can be decided by simple

\footnotetext{
${ }^{16}$ See Salminen 2014.

${ }^{17}$ Salminen 2010a, pp. 509-527.
} 
majority. Whereas EU membership was brought into force internally by the use of the institution of exceptive enactments allowing for the adoption of legislation conflicting with the Constitution and thus placing membership principally outside the Constitution as a conflicting phenomenon, the current Constitution expresses a constitutional commitment towards the Union and provides a specific provision for the transfer of powers to the Union. Now, only a significant transfer of powers to the EU requires a qualified majority, and the application of the institution of exceptive enactments is no longer needed for such transfer. The domestic debate over the competence of the President to represent Finland in the European Council also needed some clarification. The finishing touch was added after the Lisbon Treaty had already entered into force with a new provision explicitly providing that the Prime Minister represents Finland in the European Council. In addition, an amendment was made in the domestic catalogue of fundamental rights due to EU membership by adding the right to vote in elections to the European Parliament to the participatory rights of the citizen.

After these changes, Sect. 1(3) of the Constitution provides as follows:

Finland participates in international co-operation for the protection of peace and human rights and for the development of society. Finland is a Member State of the European Union (emphasis added, 1112/2011, entry into force 1.3.2012).

Currently, Sect. 94 on the acceptance of international obligations and their denouncement and Sect. 95 on the entry into force of international obligations include the possibility for the transfer of the powers according to the constitutional system and provide a decision making procedure for this purpose:

\section{Section 94}

The acceptance of the Parliament is required for such treaties and other international obligations that contain provisions of a legislative nature, are otherwise significant, or otherwise require approval by the Parliament under this Constitution. The acceptance of the Parliament is required also for the denouncement of such obligations.

A decision concerning the acceptance of an international obligation or the denouncement of it is made by a majority of the votes cast. However, if the proposal concerns the Constitution or an alteration of the national borders, or such transfer of authority to the European Union, an international organisation or an international body that is of significance with regard to Finland's sovereignty, the decision shall be made by at least two thirds of the votes cast. (1112/2011, entry into force 1.3.2012)

An international obligation shall not endanger the democratic foundations of the Constitution.

\section{Section 95}

The provisions of treaties and other international obligations, in so far as they are of a legislative nature, are brought into force by an Act. Otherwise, international obligations are brought into force by a Decree. (1112/2011, entry into force 1.3.2012)

A Government bill for the bringing into force of an international obligation is considered in accordance with the ordinary legislative procedure pertaining to an Act. However, if the proposal concerns the Constitution or a change to the national territory, or such transfer of authority to the European Union, an international organisation or an international body that is of significance with regard to Finland's sovereignty, the Parliament shall adopt it, without 
leaving it in abeyance, by a decision supported by at least two thirds of the votes cast. (1112/2011, entry into force 1.3.2012)

An Act may state that for the bringing into force of an international obligation its entry into force is provided by a Decree. General provisions on the publication of treaties and other international obligations are laid down by an Act.

Reflecting the multilevel setting and the status of the citizens as citizens of the Union as well, Sect. 14(2) on participatory rights now states:

Every Finnish citizen and every other citizen of the European Union resident in Finland, having attained eighteen years of age, has the right to vote in the European Parliamentary elections, as provided by an Act.

Considering the changes in the Constitution which had resulted from membership in the EU but which did not mention this context in the text, Sect. 9(3) on the freedom of movement was amended in 2007 after it had previously been altered through an exceptive enactment when the European Arrest Warrant was brought into force in Finland (see Sect. 2.3). ${ }^{18}$

Furthermore, EU law also shaped the reform of the domestic system for the protection of fundamental rights in the mid-1990s. At the time, a relatively widespread concern was that EU membership might somehow dilute the domestic standard of rights protection. ${ }^{19}$ (See the more detailed discussion in Sect. 2.1.1).

1.2.2 The procedure of constitutional amendment The procedure for constitutional enactments has remained unchanged since the entry into force of the Constitution Act of 1919. Currently, Sect. 73 of the Constitution provides as follows:

A proposal on the enactment, amendment or repeal of the Constitution or on the enactment of a limited derogation of the Constitution shall in the second reading be left in abeyance, by a majority of the votes cast, until the first parliamentary session following parliamentary elections. The proposal shall then, once the Committee has issued its report, be adopted without material alterations in one reading in a plenary session by a decision supported by at least two thirds of the votes cast. However, the proposal may be declared urgent by a decision that has been supported by at least five sixths of the votes cast. In this event, the proposal is not left in abeyance and it can be adopted by a decision supported by at least two thirds of the votes cast.

Thus, the normal constitutional amendment procedure requires leaving the bill in abeyance after an election. This may only be avoided in a case of urgency and if the decision on urgency is supported by at least five-sixths of the votes cast. In normal cases, which are also most frequent in practice, an amendment can be assessed by the electorate due to its being held in abeyance until after the next elections.

However, in this context one has to consider the most peculiar thing in the Finnish legal system, the institution of exceptive enactments. As explained above,

\footnotetext{
${ }^{18}$ See discussion in Ojanen 2006, pp. 89-100, and from the point of view of amending the Constitution, Salminen 2010b, pp. 161-177, and Viljanen 2009, pp. 57-88.

${ }^{19}$ See for example discussion in Ojanen 2004, pp. 541-544.
} 
the institution has its roots in the era when Finland was a Grand Duchy in the Russian Empire. While the Finns, in the legal positivist spirit, urged the Russians to abide by Finland's constitutional enactments that originated in the period of Swedish rule, there was an acute need for modern legislation, and the institution of exceptive enactments was invented to circumvent deadlocks in situations where there was no wish to amend the Constitution formally. Basically, an exceptive enactment enables the adoption of legislation that in substance conflicts with the Constitution without amending the text thereof, subject to the proviso that such legislation be approved in accordance with the procedure for constitutional enactments. A 'hole' in the Constitution is made by an exceptive enactment and filled with the relevant norms of the exceptive enactment. In recent decades, the institution of exceptive enactments has often been used for the purpose of bringing international treaties that conflict with the Constitution into force. Exceptive enactments relating to international treaties can also be enacted through a less arduous procedure than other exceptive enactments, as a two-thirds majority of the votes cast in Parliament suffices for bringing into force international obligations that conflict with the Constitution. By contrast, exceptive enactments in purely domestic matters are enacted through a procedure for constitutional enactments that requires that the bill be left in abeyance until after an election, provided that the bill is not declared urgent by a decision made by at least five-sixths of the votes cast. In addition, the bill must be adopted by a decision supported by at least two-thirds of the votes cast (Sect. 73 of the current Constitution). ${ }^{20}$

1.2.3 The background to EU amendments As an example of the exceptive amendments, the 1994 Treaty of Accession of Finland to the EU was deemed to be in conflict with the Constitution, mainly because of incompatibility between Finland's sovereignty and the transfer of powers to the EU. However, instead of amending the Constitution, the Treaty of Accession was incorporated into Finnish law through an exceptive enactment approved by a two-thirds majority in Parliament. The same procedure was applied to incorporate the Treaty of Amsterdam, the Constitutional Treaty and the Lisbon Treaty into Finnish law. As the Nice Treaty was not considered to be in conflict with the Constitution, its incorporation was approved by simple majority.

When the Constitution of 2000 was enacted, there was not enough political will to express EU membership in the text of the Constitution in a clearer manner at that stage. This minimalistic approach was probably also a result of Finland not having been a Member State for a longer period. Additionally, in the context of incorporating the treaties into the Finnish legal system, the institution of exceptive enactments was considered a useful procedure. However, the first steps in the waning of this particular institution were taken already at this stage. Limitations to the usage of exceptive enactments were enacted and developed in legal research in particular. $^{21}$ Contrary to the previous situation, in discussions surrounding the recent

\footnotetext{
${ }^{20}$ See generally Ojanen 2013, pp. 104-106, and Suksi 2011, pp. 101-105.

${ }^{21}$ See especially Viljanen 1999.
} 
amendment, emphasis was put on the correctness of the Constitution. It was underlined that the Constitution should in principle give a clear and accurate picture of the constitutional reality. If a great amount of public power that is relevant to Finland and in Finland, both with regard to state organs and individuals, is exercised in the context of the EU, this should be reflected in the text of the Constitution as well. There was a need to be more transparent and open on this question. The Constitution might otherwise risk losing its relevance as lex fundamentalis. ${ }^{22}$

The reform of 2012 included several EU motivated issues. Most importantly, a new procedure for transfers of power was introduced. This was from the beginning built on the dynamic idea of transferring powers and also explicitly mentioning the EU in this provision, because the majority of transferred powers relate to membership in the Union. As usual in Finland, when amending the Constitution, the changes were explained as being mostly a codification of the state practice and interpretations that already existed. Thus, the amendments were motivated mainly by a desire to make EU membership visible in the text of the Constitution. The idea not the change the fundamentals of the membership was underlined. Nevertheless, the new procedure for the transfer of powers to the EU in principle signified a very important change in the very elementary features of membership. ${ }^{23}$ Additionally, the explicit mention of Union membership among the fundamentals of the Finnish Constitution in its first Chapter clearly shows commitment towards Union membership and binds the Finnish Constitution with European integration.

The recent reforms were greatly supported by legal scholars, and the advice of scholars was followed. ${ }^{24}$

1.2.4 Although there are some inconsistencies in the Constitution now that EU affairs have been placed among international affairs in the system of the Constitution, there are currently no calls for amending the Constitution because of any issue relating to membership in the EU.

\subsection{Conceptualising Sovereignty and the Limits to the Transfer of Powers}

1.3.1 The new provisions of the Constitution of Finland explicitly provide that a significant transfer of state powers to the EU or an international organisation requires a two-thirds majority of votes cast in Parliament (Sect. 94(2) and Sect. 95 (2)). This also means that transfers of 'insignificant' powers can be decided by simple majority. Whereas Union membership was brought into force internally by the use of the institution of exceptive enactments that allows for the adoption of

\footnotetext{
${ }^{22}$ See Salminen 2010b, pp. 161-177.

${ }^{23}$ See Salminen 2015.

${ }^{24}$ See for example the articles Salminen 2010a, b and Salminen 2009, pp. 269-283 and compare with the amendments. The result seems to follow the suggested lines of the revision.
} 
legislation that conflicts with the Constitution and thus places membership principally outside the Constitution as a conflicting phenomenon, the current Constitution expresses a constitutional commitment towards the Union and provides a specific provision for the transfer of powers to the Union. Now, the Constitution recognises transfers of powers and, additionally, only a significant transfer of powers to the EU requires a qualified majority; the application of the institution of exceptive enactments is no longer needed for such transfer. As such, the idea of the provision is clearly based on a transfer, not on a limitation of state powers. The amendment shows a dynamic - instead of static - understanding of the integration norm of the Finnish Constitution. In the interpretation of a possible transfer, one has to also take into consideration that Finland is already a member of the EU, which is part of the fundamental organisation of Finland according to the Constitution as well (Sect. 1(3)). ${ }^{25}$

Neither the incorporation Act of the Accession Treaty nor the Constitution contain any provisions on the domestic effects and status of EU law within the Finnish legal system. Nevertheless, the travaux préparatoires reflect the idea of their status and effects according to the view of the EU. The standard understanding is that EU law enjoys legal effects and status as prescribed by EU law and interpreted by the Court of Justice of the European Union (CJEU). Nevertheless, this opinion is not straightforward, and opinions vary when it comes to possible collisions in the constitutional sphere. ${ }^{26}$ Thus, the issue is much more nuanced. The situation has now also been modified by the recent amendments, and it is evident that they show a clearer constitutional commitment towards EU membership and various obligations stemming from it. In the national implementation of EU legislation, the constitutional requirement that the domestic standard of protection of constitutional and human rights not be compromised has on some occasions limited the implementation of EU law. However, in some cases, the practice has been more adaptive and flexible. ${ }^{27}$ It has been noted that the Finnish system, which gives Parliament and its Constitutional Law Committee the opportunity to take part in the preparation of national positions on proposals for EU secondary legislation, allows them to express opinions to guide the Government and avoid possible conflicts prior to the adoption of a final EU legislative act.

1.3.2 For Finland, it is certainly fair to say 'that an older interpretation of absolute sovereignty has been replaced by a modern, revised approach' (cf. the Questionnaire) during EU membership. The concept has gone through a remarkable change. Whereas every international obligation prior to EU membership was considered to be in grave conflict with the Constitution - like EU membership itself as it was considered to affect Finnish sovereignty - today, the understanding of the concept has developed to mean that being a member in this kind of arrangement is a use of sovereignty. Thus, the construction of the constitutional concept of

\footnotetext{
${ }^{25}$ Salminen 2015.

${ }^{26}$ See discussion in Heinonen 2012.

${ }^{27}$ See especially Ojanen 2009c, pp. 129-174, Ojanen 2003 and Ojanen 2004, p. 542.
} 
sovereignty is very different, to say the least. The sovereignty of Finland is qualified by the international obligations binding on Finland. Among them, membership in the EU has special status. ${ }^{28}$

1.3.3 With the entry into force of the Constitution of 2000, formulations which had first appeared in legal research and in the practice of the Constitutional Law Committee found their way into the Constitution and its travaux préparatoires. In the travaux, the EU was accorded special status, which was soon also recognised in the practice of the Constitutional Law Committee, and thus there is far greater tolerance for limitations on sovereignty stemming from membership in the EU than those arising from international obligations. The openness towards the EU has been further modified by the latest amendments of 2012, which clearly underline the commitment towards European integration. ${ }^{29}$ There are, however, some countertendencies in the constitutional practice. The recent events and legal implications of the crisis of the monetary and economic union have once again raised some concerns about sovereignty. In this context, the Finnish position that unanimous decision-making protects Finnish sovereignty and especially the budgetary powers of Parliament can be understood as a sign that changes in attitudes towards integration are not yet consistent. ${ }^{30}$

Prior to the Constitution of 2000, the constitutional acts did not include any explicit limits to the use of exceptive enactments. The Constitution of 2000 introduced limitations to the use of exceptive enactments and to acceptance of international obligations. According to Sect. 73 of the Constitution, a derogation made by an exceptive enactment to the Constitution has to be limited in nature. Additionally, another possible limitation was introduced, since according to Sect. 94(3), an international obligation shall not endanger the democratic foundations of the Constitution. Both of these requirements were interpreted in the context of the Constitutional Treaty and the Lisbon Treaty. ${ }^{31}$ Because of the recent changes, the transfers of powers no longer have the status of exceptive enactments, and the limitations enacted for the use of exceptive enactments are no longer applicable. Nevertheless, the requirement of Sect. 94(3) of the Constitution is still applicable as it concerns international obligations as such. The issue of democratic foundations has not really been developed in the constitutional practice of the Constitutional Law Committee: this is because there have not, obviously, been any situations in which there has been a need for this. However, when the Constitutional Treaty was

\footnotetext{
${ }^{28}$ For an extensive recent analysis of the change in the concept of sovereignty in Finnish constitutional law and doctrine see Mutanen 2015 who concludes that Finland has moved from a 'sovereignist to a non-sovereignist Constitution' (p. 359); the sovereignty provisions, read together with the amendments, have acquired a new meaning and have led to a more integration-friendly understanding in the Finnish legal discourse. See especially Ojanen 2004 and Salminen 2004.

${ }^{29}$ Salminen 2015.

${ }^{30}$ See discussion in Leino and Salminen 2013.

${ }^{31}$ Opinions 13/2008 (on the Treaty of Lisbon) and 36/2006 (on the Constitutional Treaty) of the Constitutional Law Committee of Parliament (hereinafter Constitutional Law Committee).
} 
incorporated into Finnish Law, this Section was referred to upon consideration of whether the Union, based on the Constitutional Treaty, would endanger the democratic foundations of the Constitution. ${ }^{32}$ In so doing, special emphasis was put on the reforms which were put in effect later by the Lisbon Treaty.

No particular field of state powers nor any fields of legislation are excluded from a possible transfer of powers. However, any transfer of powers based on an international obligation shall, according to Sect. 94(3), not endanger the democratic foundations of the Constitution. This could be considered as a limit to or at least as a condition for such a transfer.

1.3.4 The Finnish Supreme Courts - both the Supreme Court and the Supreme Administrative Court - apply EU law, and accept both direct effect and primacy per se. However, not many cases have been reported in which the courts have set aside Finnish legislation or a conflict has been identified where EU law was of relevance. In particular, there are no reports concerning cases where EU law has allegedly been in conflict with the very fundamental questions of Finnish fundamental rights. In addition, it seems that the Finnish courts are not very active in making references to the CJEU either. These features might have many explanations. However, the primary explanation is not that there is resistance to EU law as such. There might be a tendency to resolve any possible prima facie conflict by interpretation via an EU-friendly interpretation, for which at least the Finnish Constitution now provides many possible legal arguments. The fact that the courts have never made a reference to the CJEU concerning the validity of EU secondary law might, however, be based in the Finnish constitutional culture, for which the possibility to question the validity of a legislative act on the basis of a constitutional argument is a relatively new phenomenon.

Noteworthy in the Finnish context is, of course, that the Constitutional Law Committee has stated that the domestic implementation of directives and other EU instruments cannot weaken the domestic standard of rights protection. ${ }^{33}$ Typically, this has not proved to be a problem at all. Since EU measures that regulate the rights and obligations of individuals or are otherwise of a legislative nature within the meaning of the Finnish Constitution must be implemented by Acts of Parliament in accordance with the same procedure as for domestic legislative enactments, the Constitutional Law Committee may also review the constitutionality of domestic implementing enactments of EU measures. The implementation of EU measures should conform to the requirements originating in the domestic system for the protection of constitutional and human rights. This is, of course, a bold statement, and implementation seems to be rather flexible; there are many ways to adapt and conform with the requirements of European law. The obvious tendency seems to be towards a fusion of the various regimes and their requirements. As EU proposals for legislation may be reviewed by the Constitutional Law Committee, potential problems can be addressed before the relevant national legislation is passed.

\footnotetext{
32 Opinion 36/2006 (on the Constitutional Treaty) of the Constitutional Law Committee.

${ }^{33}$ E.g. Opinion 25/2001 of the Constitutional Law Committee.
} 


\subsection{Democratic Control}

1.4.1 Already for membership in the European Economic Area, the constitutional acts were amended so as to provide for the strong participation and information rights of Parliament.

Regarding the procedural requirements, Sect. 96(2) of the Constitution (for the text of the relevant provisions see Sect. 1.2.1) specifies the ways in which the Government must communicate the proposals for EU acts, agreements and other measures without delay in order to determine Parliament's position. In matters that fall within Parliament's competence, its position in practice equals the Finnish position, even if Parliament usually leaves the details to the Government's discretion and limits itself to steering the main political lines. Union proposals are considered by the Parliament's Grand Committee and usually also in one or more of the sub-committees. The Government is obliged to keep the relevant committees updated with information on the negotiations and to keep the Grand Committee informed of its position. Section 97 includes provisions on Parliament's right to receive information on international affairs. It requires the Government to keep the Grand Committee informed through reports on the preparation of EU matters other than those falling under Sect. 96, either upon request or when otherwise necessary. This concerns, for example, the preliminary stages of a decision making process or matters in which the Council does not formally act. Under Sect. 97(2), the Prime Minister is required to provide information on matters on the European Council agenda, both before and after its meetings, and on envisaged amendments to the Treaties. On the basis of the information provided, the committees, including the Constitutional Law Committee, may issue statements to the Government.

There is a widely shared view that the system functions well. Of further relevance here is that the traditional interpretation of Sects. 96 and 97, which have generally been understood to extend beyond matters that formally belong to Union competence to questions that can be considered 'comparable' to Union matters, both as regards their substance and their effects. ${ }^{34}$ The Constitutional Law Committee has interpreted many measures as matters belonging to Sect. 96 or 97, whether formally taken within the Union framework or not. It has thereby allocated the primary competence in these matters to the Government under Sect. 93(2), equally placing it under a strict obligation to report to Parliament on all matters falling under the competence of the latter.

1.4.2 Finnish constitutional history records only two referendums, of which one was held on the very matter of the accession of Finland to the Union. ${ }^{35}$ The Finnish Constitution provides for the possibility of a consultative referendum, on which a

\footnotetext{
34 Viljanen 2003, and Ojanen 2004.

35 The other was the advisory referendum organised in the 1930s post legem on the Prohibition Act that limited the production, sale and consumption of alcoholic beverages.
} 
decision shall be made by an Act of Parliament. Today there is the additional possibility of a citizens' initiative pursuant to Sect. 56 of the Constitution.

\subsection{The Reasons for, and the Role of, EU Amendments}

1.5.1-1.5.3 The recent EU related amendments of the Finnish Constitution were mostly motivated by the desire to improve the openness and transparency of the Constitution. As an argument, the completeness of the Constitution was used in the meaning that the Constitution should give an accurate picture of the constitutionally relevant issues in Finland. ${ }^{36}$ When the Constitutional Treaty and Lisbon Treaty were incorporated into Finnish law, the Constitutional Law Committee of Parliament in particular raised this issue. However, amendment was not constitutionally required. The Committee only advised that there would be reason to consider amending the Constitution both regarding the special provision concerning the transfer of powers and regarding the need to expressly mention the EU. ${ }^{37}$

In the preparation of the EU related amendments, the most important rationale was the need to take the Constitution seriously and to reflect the shift of power to the supranational level. ${ }^{38}$ It was motivated by the need for transparency and the requirement of the completeness of the Constitution. Many comparisons were made between various solutions within various Member States, but no clear common denominator was found. There was also some discussion in the Finnish legal literature on this issue. ${ }^{39}$

When evaluating the current state of the Finnish Constitution and its EU related amendments adopted during Finland's EU membership, there seems to be good reason to consider that the relationship between the EU and Finland and Finland as an integrated state have matured. EU membership and the further constitutionalisation of the EU have not rendered the national constitution useless. The Finnish discourse has found it important to strike a balance between national constitutional law and European constitutional law. The amendments contribute to this balance. While they interconnect the orders, they also clearly open the orders to mutual influence. Opening and constitutionalising EU membership on the national constitutional level does not weaken the Constitution for Finland. On the contrary, it has opened new perspectives and possibilities for reciprocal stabilisation.

\footnotetext{
${ }^{36}$ Salminen 2010a, b.

37 Opinions 13/2008 (on the Treaty of Lisbon) and 36/2006 (on the Constitutional Treaty) of the Constitutional Law Committee.

${ }^{38}$ Thus, the guidelines in Claes 2005 and Albi 2005 were followed, as suggested by Salminen 2010a, b.

${ }^{39}$ See also Mutanen 2015, pp. 310-323.
} 


\section{Constitutional Rights, the Rule of Law and EU Law}

\subsection{The Position of Constitutional Rights and the Rule of Law in the Constitution}

2.1.1 A comprehensive reform of the domestic system for the protection of constitutional rights and human rights entered into force on 1 August 1995. International human rights treaties binding on Finland, with the ECHR at their apex, featured as the main source of inspiration and stimulus for this reform. As a result of the reform, the current fundamental rights catalogue in Chap. 2 of the Constitution of Finland is broad and comprehensive. It sets out a range of economic, social and cultural rights, in addition to traditional civil and political rights. Moreover, there are specific provisions on such rights as everyone's responsibility for the environment and environmental rights (Sect. 20), the right to a fair trial before an independent and impartial court or tribunal within a reasonable time (Sect. 21(1)) and on the right to good administration (Sect. 21(2)). As a rule, fundamental rights are granted to everyone, with an exception being made only with regard to freedom of movement (Sect. 9) and certain electoral rights (Sect. 14). ${ }^{40}$

The domestic standard of protection of fundamental rights is intended to ascend to a high level. The established constitutional doctrine is that international human rights obligations binding on Finland feature as a minimum standard of protection. ${ }^{41}$ However, the de facto implementation of this doctrinal premise leaves a lot to be desired in light of critical observations on the situation of human rights in Finland by international treaty bodies. For instance, since the entry into force of the ECHR in 1990, the European Court of Human Rights (ECtHR) has found a violation by Finland in well over 100 judgments. $^{42}$

Just before Finland joined the EU in 1995, there was concern that EU membership might somehow dilute the domestic standard of fundamental rights protection, particularly in the areas of social rights and good administration. In light of this concern, some provisions of the 1995 Constitutional Rights Reform were deliberately designed to feature as 'constitutional self-defence' against such problematic tendencies that might in the long run arise from EU membership. A reference can be made to a provision on the right of access to information (Sect. 12(2)) and a relatively far-reaching clause in Sect. 19 on the right to social security, guaranteeing social rights to everyone. Some social rights, either by means of the relevant

\footnotetext{
${ }^{40}$ See e.g. Scheinin 1996, pp. 257-280. On economic, social and cultural rights under the Finnish Constitution, see Scheinin 2001. A thorough Finnish Constitutional Rights Commentary is provided by Hallberg et al. 2011.

${ }^{41}$ See the preparatory works of the reform of the domestic system for the protection of constitutional rights, such as Government Bill 309/1993 and Report 25 of 1994 of the Constitutional Law Committee.

${ }^{42}$ The major problem area has related to Art. 6 of the ECHR, but there are relatively many judgments by the ECtHR finding a violation by Finland of Arts. 8 and 10 of the ECHR.
} 
constitutional provision itself, or by means of Acts of Parliament, have also been guaranteed as subjective rights directly enforceable through the courts. ${ }^{43}$ Similarly, Sect. 21(2), which guarantees various attributes of the right to good administration, may also be understood as imposing constitutional constraints on the potentially harmful effects of European integration. As will be discussed in more detail below, the domestic standard of protection of constitutional and human rights has occasionally de facto compromised the maximal implementation of certain EU legal measures.

While the current catalogue of constitutional rights is comprehensive insofar as the substantive rights provisions are concerned, the Constitution of Finland is largely, if not exclusively, silent on several important doctrines and principles pertaining to the domestic protection of constitutional and human rights. Hence, one must delve into the practice of the leading authority on constitutional interpretation in Finland, the Constitutional Law Committee of Parliament, and the travaux préparatoires of the reform of Constitutional Rights Catalogue in order to get a grip on them. For the present purposes, the following doctrines and principles pertaining to constitutional rights are worthy of elaboration:

(i) Direct applicability and interpretive effect of constitutional rights. According to the travaux préparatoires of the Reform of Constitutional Rights Catalogue, one of the major aims of the reform was to increase the direct application of constitutional rights by domestic courts and authorities. This aim has also materialised in subsequent domestic court practice, in which courts have not only invoked several provisions on civil and political rights but have also treated several dimensions of social rights as 'justiciable'. However, the direct applicability of constitutional rights is watered down by what can be called a minimalist approach to constitutional rights and human rights: Finnish courts far too often tend to be satisfied with the minimum standard of protection under the ECHR, as indicated by the existing case law of the ECtHR. This practice already contradicts such a fundamental principle regarding the relationship between constitutional rights and international human rights as is the premise that domestic courts should provide rights protection beyond the threshold where the ECtHR would find a violation of the ECHR. ${ }^{44}$

Moreover, it is firmly established doctrine that courts and authorities should resort to a 'constitutional rights-oriented' approach to the interpretation of domestic statutes, in order to avoid conflicts between constitutional rights and domestic legislation, as well as to promote the effective observance of these rights. In everyday court practice the interpretive effect of

\footnotetext{
${ }^{43}$ Finnish courts have treated several dimensions of social rights as 'justiciable'. See e.g. the following judgments of the Supreme Administrative Court: KHO 2000:36, KHO 2001:35 and KHO 2001:50.

${ }^{44}$ For minimalist approaches by Finnish courts and authorities regarding constitutional and human rights, see in detail Lavapuro et al., pp. 523 and 524.
} 
constitutional rights is clearly the primary method of giving judicial effect to constitutional rights. As it has been impossible to keep the interpretation of constitutional rights provisions intact and untouched by the influence of international human rights norms, the outcome has also been a human rights-oriented approach to the interpretation of Finnish law, including the Constitution. $^{45}$

(ii) The semi-constitutional status, direct applicability and interpretive effect of international human rights treaties. The third notable characteristic of the domestic system for the protection of constitutional rights is the convergence of the effects of constitutional rights and international human rights treaties. Aside from providing a major source of inspiration for the concrete formulations of the various material provisions on constitutional rights and the methods of giving legal protection to constitutional rights, human rights treaties binding on Finland assume a semi-constitutional status in the Finnish legal order. This feature originates in several constitutional provisions that make explicit reference both to domestic constitutional rights and to international human rights. ${ }^{46}$

However, aside from producing interpretive effect, the predominant method of implementation of human rights treaties, the method of incorporation through an Act of Parliament, warrants the direct application of human rights by domestic courts and authorities. ${ }^{47}$ As human rights treaties have invariably been incorporated through Acts of Parliament, human rights treaties enjoy firm formal status as Acts of Parliament within the Finnish legal order so that they are in force in Finnish law according to their content in international law, as seen in the light of the case law of their international treaty bodies (and also in in their authentic languages which are decisive in the case of questions of interpretation originating in translation errors or ambiguities). ${ }^{48}$

(iii) The position of general principles of law in the Constitution. The Constitution of Finland is largely, if not exclusively, silent on such general

\footnotetext{
45 This was established in Opinion 2/1990 of the Constitutional Law Committee. The principle of a human-rights-friendly interpretation was reiterated in the context of the 1995 constitutional rights reform.

${ }^{46}$ See Scheinin 1996, p. 276.

${ }^{47}$ See Scheinin 1996, p. 259. Also the Constitutional Law Committee of Parliament noted in its Opinion 2/1990 that the method of incorporation entails the direct applicability of human rights treaties by domestic courts and authorities.

${ }^{48}$ See e.g. Opinion 2/1990 of the Constitutional Law Committee on the direct applicability of the ECHR due to the method of incorporation. For example, the Supreme Court of Finland has explicitly stated that the ECHR and the ICCPR are 'part of the law of the land' due to the method of incorporation by an Act of Parliament. See e.g. the decision of the Supreme Court, KKO 1993:19.
} 
principles of law as legal certainty and legitimate expectations. However, both international human rights treaties and EU law have promoted a general awareness among the Constitutional Law Committee of Parliament and Finnish courts and authorities of the significance of these principles in the context of cases pertaining to constitutional and human rights and issues of constitutional law in general. Hence, the practice of both the Constitutional Law Committee of Parliament and the domestic courts indicates that the principles of legal certainty and legitimate expectations have a firm place in domestic constitutional reasoning, e.g. in the context of cases pertaining to the right to property (Sect. 15) or to the freedom to engage in commercial activity (Sect. 18). ${ }^{49}$

While the general principles of law are generally recognised at the level of constitutional doctrine, the principle of non-retroactivity features as an exception to the rule, to the extent that Sect. 8 of the Constitution explicitly recognises the prohibition of non-retroactivity in criminal cases (see Sect. 2.3.2). ${ }^{50}$ However, the other dimensions of the principle of non-retroactivity have gained a firm foothold in constitutional practice through the Constitutional Law Committee and courts. ${ }^{51}$

2.1.2 The criteria for limiting constitutional rights The Constitution of Finland lacks a provision stipulating the conditions under which restrictions can be imposed on constitutional rights. However, it is firmly established constitutional doctrine that all interferences with constitutional rights must be reviewed by the Constitutional Law Committee of Parliament or the domestic courts in accordance with the following seven distinct, yet interrelated conditions:

(i) Limitations must be provided by an Act of Parliament.

(ii) Legislative provisions on limitations must be sufficiently clear and precise.

(iii) The essence of a constitutional right cannot be subject to limitations.

(iv) Limitations must have a legitimate aim that corresponds to the objectives of general interest or the need to protect the fundamental rights of others.

(v) Limitations must conform to the principle of proportionality, including be necessary for genuinely reaching the legitimate aim.

(vi) Limitations must be in conformity with human rights obligations binding on Finland.

\footnotetext{
${ }^{49}$ See e.g. Opinions 33/2002, 45/2002, 21/2004, 25/2005, 42/2006 of the Constitutional Law Committee.

${ }^{50}$ Section 8 of the Constitution, entitled 'The principle of legality in criminal cases', provides as follows: 'No one shall be found guilty of a criminal offence or be sentenced to a punishment on the basis of a deed, which has not been determined punishable by an Act at the time of its commission. The penalty imposed for an offence shall not be more severe than that provided by an Act at the time of commission of the offence.' (Emphasis added).

${ }^{51}$ See e.g. Opinions 33/1998, 34/1998, 37/1998, 63/2002 and 42/2006 of the Constitutional Law Committee.
} 
(vii) There must exist adequate legal safeguards (judicial review, the right to appeal, the right to be heard, etc.) regarding interferences with constitutional rights. ${ }^{52}$

Each condition listed above has an autonomous function to fulfil. As these conditions are cumulative, one failure suffices to result in a conclusion that an interference amounts to a violation of the Constitution. Given all these characteristics, the permissible limitations test under the Constitution of Finland is one of those concrete arrangements that generates both substantive and doctrinal coherence between the ECHR and other human rights treaties, notably the International Covenant on Civil and Political Rights (ICCPR), as well as the EU Charter of Fundamental Rights. Yet, as international human rights treaties feature as a minimum standard of rights protection, the permissible limitations test under the Constitution of Finland is, at least potentially, more rigorous than e.g. the standard three-partite test under the ECHR. However, it also warrants emphasis that if the Constitutional Law Committee of Parliament is of the view that a legislative proposal pending before Parliament fails under the permissible limitations test, it does not declare the legislative proposal invalid or null and void. Instead, the Committee usually proposes modifications to the bill so as to achieve compliance with constitutional and human rights.

2.1.3 The position of the rule of law Up until the entry into force of the Constitution of Finland on 1 March 2000, the principle of the rule of law remained unmentioned in the text of the Constitution. Nevertheless, some important dimensions of the rule of law, such as access to courts (Sect. 21(1)) and the requirement of limitations on constitutional rights 'being provided by the law' were recognised either within the text of the Constitution or in constitutional doctrine or practice.

Nowadays, however, the Constitution of Finland explicitly recognises the rule of law, as Sect. 2(3) provides as follows:

The exercise of public powers shall be based on an Act. In all public activity, the law shall be strictly observed.

The systematic location of this provision in Chap. 1 of the Constitution, entitled 'Fundamental provisions', also reveals that the rule of law is one of the most fundamental principles of the Constitution, alongside sovereignty, the inviolability of human dignity and the freedom and rights of the individual, justice, democracy, parliamentarism and the separation of powers.

Moreover, such elementary dimensions or attributes of the rule of law as the principle of legality - particularly the requirement that the rights and obligations of individuals be provided by an Act of Parliament - or access to courts are relatively frequently invoked by individuals before domestic courts. Administrative courts in

\footnotetext{
${ }^{52}$ See Report 25/1994 of the Constitutional Law Committee, pp. 4-5. For a comprehensive examination of the permissible limitations test under the Constitution, see Viljanen 2001.
} 
particular have treated the rule of law as justiciable in reviewing the legality of administrative decisions or other measures; several Opinions of the Constitutional Law Committee of Parliament in the context of ex ante review of legislative proposals include explicit references to the rule of law principle. ${ }^{53}$

\subsection{The Balancing of Fundamental Rights and Economic Freedoms in EU Law}

2.2.1 As already noted in Sect. 2.1.1, on the verge of Finnish EU membership in the mid-1990s, there was concern that European integration might dilute the domestic protection of fundamental rights. One of the major reasons for this anxiety was the thinking that such economic market freedoms as the free movement of goods and workers or the freedom of establishment and freedom to provide services in particular constituted the 'core' of the EU legal order, whereas the protection of fundamental rights featured only as a dimension of EU law, with the result that economic freedoms tended to have an edge over fundamental rights in cases involving balancing between economic freedoms and fundamental rights.

While these domestic concerns have not been totally groundless, they have nonetheless proved to be exaggerated. The years of EU membership since 1995 have not prompted any widespread or serious concern about the EU excessively prioritising economic liberties over fundamental and human rights. Although the tendency in recent years has been towards the weakening of the welfare state and the lowering of the standard of protection of social rights, it is submitted here that EU law or EU membership in general has not been a major impetus for this tendency.

However, some individual judgments by the CJEU in cases such as Laval and Viking ${ }^{54}$ in particular have generated some domestic debate over the appropriate balance between economic freedoms and fundamental rights. However, instead of any straightforward and unanimous view that the balance has tilted too far in the direction of economic freedoms at the expense of fundamental rights, the domestic views regarding these two cases have been relatively polarised, especially among the Finnish economic and political elite. While some have hailed these decisions from a free market perspective, others have criticised them, particularly from a labour law perspective for their interference with the fundamental premises of collective labour law and the industrial relations of states. ${ }^{55}$

In addition, the so-called euro crisis has prompted constitutional concern regarding the effects of the crisis on the appropriate protection of fundamental social rights. ${ }^{56}$

\footnotetext{
${ }^{53}$ See Opinions 21/2009, 67/2010 and 33/2012 of the Constitutional Law Committee.

${ }^{54}$ Case C-438-/05 Viking [2007] ECR I-10779; Case C-341/05 Laval [2007] ECR I-11767.

${ }^{55}$ See e.g. Ojanen 2011, pp. 127-131.

${ }^{56}$ See Tuori and Tuori 2014.
} 


\subsection{Constitutional Rights, the European Arrest Warrant and EU Criminal Law}

\subsection{1-2.3.3 The presumption of innocence, nullum crimen, nulla poena sine lege, fair trial and in absentia judgments}

In Finland, the Constitutional Law Committee reviewed both the proposal for the Framework Decision on the European Arrest Warrant ${ }^{57}(\mathrm{EAW})^{58}$ and its domestic implementing enactment ${ }^{59}$ for compatibility with the Constitution and international human rights obligations binding on Finland. However, the constitutional observations by the Committee revolved around other issues pertaining to the EAW, such as the extradition of Finnish citizens, the rule of double criminality, the extradition of minors, the protection of family life and certain other issues relating to fundamental and human rights. In particular, the extradition of Finnish citizens and the issue of dual criminality warranted constitutional attention by the Committee, simply because Finland at the time in the early 2000s still adhered to the principle of double criminality and the prohibition on extraditing Finnish nationals. ${ }^{60}$

By contrast, the Constitutional Law Committee remained totally silent on the issue of the presumption of innocence within the context of the European Arrest Warrant. Neither have concerns with regard to the presumption of innocence arisen in domestic court proceedings. ${ }^{61}$ In fact, any concern over the appropriate observance of the right to a fair trial, including the presumption of innocence, has only been voiced by some individual judicial actors, such as the President of the Supreme Court of Finland, Justice Pauliine Koskelo, in some of her public remarks.

While the abolition of double criminality was one of the issues that warranted the attention of the Constitutional Law Committee of Parliament, it should be emphasised that the Committee eventually did not find this issue to be a reason for constitutional concern. Instead, the Committee took the view that the domestic implementing act for the European Arrest Warrant limited the scope of application of the European Arrest Warrant without verification of the double criminality of the

\footnotetext{
${ }^{57}$ Council Framework Decision of 13 June 2002 on the European arrest warrant and the surrender procedures between Member States (2002/584/JHA), [2002] OJ L 190/1.

${ }^{58}$ Opinion of $42 / 2001$ of the Constitutional Law Committee.

${ }^{59}$ Opinion of 18/2003 of the Constitutional Law Committee.

${ }^{60}$ Up until 1 October 2007, Sect. 9(3) of the Constitution of Finland provided as follows: 'Finnish citizens shall not be prevented from entering Finland or deported or extradited or transferred from Finland to another country against their will.' However, the Constitutional Law Committee (see Opinion 13/2003) regarded the EAW as prompting the need for a constitutional amendment of this constitutional provision on the extradition of Finnish citizens, so as to comply appropriately with Finland's international obligations and, specifically, obligations under EU law. The amendment entered into force on 1 October 2007 with the result that the extradition of Finnish citizens is no longer absolutely forbidden by the Constitution of Finland.

${ }^{61}$ For constitutional concerns regarding the European Arrest Warrant in Finland, see Ojanen 2009b, pp. 143-156.
} 
acts constituting such offences as could be regarded as sufficiently 'serious crimes'. In addition, the Committee noted that the offences giving rise to surrender without verification of double criminality were also largely, if not exclusively, serious crimes under domestic law. Finally, the Committee emphasised that the domestic implementing act included grounds for mandatory non-execution that appropriately limited the application of the European Arrest Warrant to what was constitutionally acceptable.

In this context, it warrants emphasis that the bill for the domestic implementing Act of the EAW (the Act on Extradition on the Basis of an Offence between Finland and Other Member States of the European Union, Act No 1286 of 2003, the so-called EU Extradition Act) included additional grounds for mandatory non-execution of an EAW on which the European Arrest Warrant Framework Decision is silent. As the Constitutional Law Committee also proposed a number of additional specifications to the domestic implementation act for the EAW in order to ensure the appropriate observance of constitutional and human rights, ${ }^{62}$ the outcome was that the maximal implementation of the EAW Framework Decision made way for the active observance of constitutional and human rights in Finland. ${ }^{63}$ Furthermore, the Committee of Legal Affairs of Parliament emphasised the need for fundamental and human rights-friendly interpretation and application of the European Arrest Warrant and its domestic implementing act, particularly insofar as such grounds for mandatory refusal under Sect. 5 of the Act on Extradition on the Basis of an Offence between Finland and Other Member States of the European Union (Act No 1286 of 2003) are concerned ${ }^{64}$ In particular, the necessity of rights-friendly application was emphasised in relation to Sect. 5(6) of the domestic implementing act, essentially requiring, inter alia, that extradition be refused if there is cause to assume that the person requested would be subjected to a violation of his or her human rights or constitutionality protected due process, freedom of speech or freedom of association. In this context, the Legal Affairs Committee explicitly emphasised the interconnections between Sect. 5(6), and such constitutional rights as the right to a fair trial under Sect. 21 of the Constitution. By contrast, however, no domestic constitutional discussion can be found on the issue of in absentia judgments. ${ }^{65}$

Overall, the domestic implementation of the European Arrest Warrant Framework Decision is one of those cases in which Finland has compromised the

\footnotetext{
${ }^{62}$ See also Opinion 48/2002 of the Constitutional Law Committee.

${ }^{63}$ For the details of the 'Finnish constitutional challenge' in the context of the domestic implementation of the EAW Framework Decision, see Ojanen 2009c.

${ }^{64}$ Report 7/2003 of the Legal Affairs Committee of Parliament.

65 The rule under Sect. 28 the Act on Extradition on the Basis of an Offence Between Finland and Other Member States of the European Union (Act No. 1286 of 2003) is clearly the presence of the individual at the proceedings, or at least he or she shall be reserved an opportunity to be heard on the contents of the request. However, Sect. 28(3) provides that if the requested person is absent from the consideration of the matter without a lawful excuse, the question may be examined and decided despite his or her absence. (Emphasis added).
} 
most effective domestic implementation of EU legislation for the sake of fundamental and human rights. Although there may thus be tension or even a conflict between the European Arrest Warrant Framework Decision and its domestic implementing act, it deserves notice that Finland was also praised by the UN Human Rights Committee for its practice of trying to appropriately integrate fundamental and human rights into various legislative instruments aimed at countering terrorism in 2004 as follows:

The Committee is pleased to observe the State party's concern to integrate human rights into action to combat terrorism, in part by maintaining an outright ban on extradition, refoulement or expulsion to a country where the individual concerned might be exposed to the death penalty and violations of articles 6 and 7 of the Covenant. (Concluding observations of the Human Rights Committee: Finland. 02/12/2004). ${ }^{66}$

The application of the European Arrest Warrant has already generated relatively voluminous case law by the domestic courts. Up until now, there has been no evidence of any judicial resistance on the part of domestic courts or authorities to apply and enforce the European Arrest Warrant. The Finnish courts have also embraced the effect of the EAW on the interpretation of Finnish law. Overall, the approach of Finnish judicial authorities to the application of the European Arrest Warrant assumes a pragmatic case-by-case approach. Each case is dealt with individually, without expressing any bold and sweeping judicial observations on the European Arrest Warrant and its relationship with Finnish law, including the domestic system for the protection of fundamental and human rights. One looks in vain for any kind of bold and sweeping observations on the 'constitutional aspects' of the EAW.

Indeed, what is still lacking is a 'hard case' inviting a Finnish court to really ponder the application of the European Arrest Framework Decision and its domestic implementing enactment in light of such constitutional and human rights as the nulla poena sine lege rule or fair trial - or the compatibility of the domestic implementing act with the European Arrest Framework Decision for that matter. ${ }^{67}$ Given how the need to adequately safeguard these rights shaped and directed the enactment of the domestic implementing legislation for the EAW, and even to the extent that it is justified to speak about 'the Finnish constitutional challenge to the European Arrest Warrant Framework Decision', extremely complicated questions concerning the status and effects of constitutional and human rights in the application of the European Arrest Warrant may sooner or later emerge. This is especially so because the highest constitutional authority of the country, the Constitutional Law Committee of Parliament, has also generally emphasised that

\footnotetext{
${ }^{66}$ Concluding observations of the Human Rights Committee: Finland. 02/12/2004. CCPR/CO/ 82/ FIN. (Concluding Observations/Comments), para. 4.

${ }^{67}$ On 25 February 2010, a reference for a preliminary ruling from the Supreme Court of Finland was lodged before the CJEU in Case C-105/10 PPU Gataev and Gataeva [2010] ECLI:EU: C:2010:176. The reference included a number of questions directly or indirectly aimed at finding out whether the domestic implementing enactment was in harmony with the Council Framework Decision on the European Arrest Warrant. However, the reference was subsequently withdrawn due to the cancellation of the arrest warrant.
} 
the domestic implementation of EU legislation is not permitted to weaken the domestic standard of protection of constitutional and human rights. ${ }^{68}$

\subsubsection{The Right to a Fair Trial - Practical Challenges Regarding a Trial Abroad}

2.3.4.1 In Finland, there has been only little discussion about the practical challenges regarding a trial abroad. However, when reviewing the proposal for the domestic implementing act for the Framework Decision on the European Arrest Warrant, the Legal Affairs Committee of Parliament briefly emphasised the importance of ensuring that in each and every case appropriate legal aid and assistance is provided to the extradited individual. Hence, the Committee emphasised that Finnish authorities should occasionally take advantage of the possibilities under the Legal Aid Act (Act No 257 of 2002) even if the starting point is that the Member State requesting the extradition of the individual is primarily responsible for providing legal aid and assistance. ${ }^{69}$

\subsubsection{The Right to Effective Judicial Protection: The Principle of Mutual Recognition in EU Criminal Law and Abolition of the Exequatur in Civil and Commercial Matters}

2.3.5.2-2 3.5.4 Beyond what was already noted about the domestic constitutional discussion surrounding the European Arrest Warrant, the principle of mutual recognition has not been a matter of constitutional concern in Finland.

\subsubsection{Constitutional Rights Regarding Other Aspects of EU Criminal Law}

There has been constitutional concern in Finland that the domestic implementation of EU criminal law may erode such fundamental constituents of the principle of legality as those originating in 'the quality of law'. After all, the principle of legality is not just confined to prohibiting the retrospective application of criminal law. In addition, this principle embodies the fundamental principle that an offence must be clearly defined in law. This condition is essentially satisfied where the wording of the relevant provision indicates what acts and omissions will give rise to the individual's criminal liability. However, it warrants emphasis that this constitutional concern over the erosion of the 'quality of law' standard has not related to the domestic implementation of EU criminal law. Instead, there has been a general constitutional concern that the domestic transposition of EU law has diluted the 'quality of law', particularly insofar as the law constitutes an interference with fundamental rights. In such situations, the permissible limitations test under the Finnish constitution requires that legislative provisions on limitations must be sufficiently clear and precise.

Against this background, the Constitutional Law Committee has emphasised that the domestic implementation of EU measures is not permitted to weaken the quality of law standard. ${ }^{70}$ In addition, it has on several occasions emphasised the

\footnotetext{
${ }^{68}$ Opinion 23/2001 of the Constitutional Law Committee.

${ }^{69}$ Report 7/2003 of the Legal Affairs Committee.

${ }^{70}$ See e.g. Opinion 9/2004 of the Constitutional Law Committee.
} 
importance of taking the quality of law standard into account when implementing EU criminal law at the level of domestic legislation. In particular, the Committee has a very negative attitude to criminalisation 'in blanco', so that the implementing act only mechanically states that the provisions of the EU measure in question 'are in force' domestically. ${ }^{71}$

From this premise, the Committee has emphasised that the appropriate method of implementing EU criminal law is transformation, i.e. enacting domestic criminal law in harmony with the EU measure in question.

By contrast, the Committee has been very critical towards using the method of incorporation so that the incorporating act simply states that the provisions of a certain EU measure 'are in force' domestically. ${ }^{72}$ Similarly, the Committee has been reserved regarding reference as a method of implementing EU criminal law. This method involves clauses in domestic legislation stipulating that a certain EU measure must be taken into account in the application of the domestic legislation in question. It deserves emphasis that these constitutional reservations by the Constitutional Law Committee regarding the use of methods of incorporation and reference also apply regarding the implementation of EU law in general, although they have become emphasised in the context of EU criminal law.

\subsection{The EU Data Retention Directive}

2.4.1 In Finland, the implementation of the EU Data Retention Directive ${ }^{73}$ in 2008 was not seen as posing a major constitutional problem. While the Constitutional Law Committee regarded the domestic implementing enactment as constituting an interference with the right to private life and the protection of personal data under Sect. 10 of the Constitution and, accordingly, considered whether such interference was justified under the permissible limitations test of the Finnish Constitution, the Committee ended up taking the view that the domestic implementing enactment passed the permissible limitations test. ${ }^{74}$ Hence, the Committee regarded the Act as being in harmony with the Constitution. The primary reason for this outcome was simply that the directive 'only' regulated the obligations of the service providers to retain such communications data as location data and traffic data. By contrast, the directive did not regulate access to such data by the competent authorities of the

\footnotetext{
${ }^{71}$ See e.g. Opinions 9/2007, 53/2006, 40/2002, 31/2002, 6/2002, 45/2001 and 5/1998 of the Constitutional Law Committee.

${ }^{72}$ The Committee adopted this view already during the very first years of EU membership. See e.g. Opinion 20/1997 of the Constitutional Law Committee.

${ }^{73}$ Directive 2006/24/EC of the European Parliament and of the Council of 15 March 2006 on the retention of data generated or processed in connection with the provision of publicly available electronic communications services or of public communications networks and amending Directive 2002/58/EC, [2006] OJ L 105/54.

${ }^{74}$ See Opinion 3/2008 of the Constitutional Law Committee.
} 
Member States for law enforcement purposes. Moreover, the Directive explicitly provided that no data revealing the content of the communication may be retained. In Finland, these characteristics of the Directive combined to make the outcome that the directive left enough leeway for the domestic legislator to take requirements stemming from constitutional rights and human rights appropriately into account in the implementation of the directive. Put differently, it can be said that Finland took advantage of the margin of discretion left by the directive in a constitutional rights-friendly way, by specifying the conditions for access to data and the length of retention in domestic law much more narrowly than in the directive. Finally, it is to be emphasised that the scope of mandatory data retention was limited only to such data that the providers of publicly available electronic communications services or of public communications networks were nonetheless generating or processing for their own commercial purposes.

Originally, the data retention directive was implemented by means of an amendment (Act No. 343 of 2008) of the Act on the Protection of Privacy in Electronic Communications (Act No. 516/2004) that was intended to ensure confidentiality and protection of privacy in electronic communications. This Act implemented Directive 2002/58/EC of 12 July 2002 of the European Parliament and of the Council concerning the processing of personal data and the protection of privacy in the electronic communications sector. ${ }^{75}$

Just recently, Finnish legislation in the area of electronic communications was subject to a very comprehensive reform, as the New Information Society Code (Act No. 917/2014) entered into force on 1 January 2015. This Code compiles all domestic legislative provisions on electronic communications, including the provisions on data retention. The Code also updates domestic legislation in areas such as e-privacy, consumer protection, communications networks and data security, and collects the formerly fragmentary legislative regime under one umbrella.

Originally, the proposal for the Information Code actually included more extensive provisions on mandatory data retention than were previously required by the Act on the Protection of Privacy in Electronic Communications; the new Code would have enabled retention of data collected in the context of browsing websites, for example.

However, when the bill concerning the New Information Society Code was pending before Parliament in spring 2014, the CJEU gave its judgment in the Digital Rights Ireland case. ${ }^{76}$ The judgment significantly affected the parliamentary deliberations on the bill.

In April 2014, the Constitutional Law Committee of Parliament gave its Opinion on the proposed legislation in light of the Constitution of Finland and the CJEU's

\footnotetext{
75 [2002] OJ L 201/37.

${ }^{76}$ Joined cases C-293/12 and C-594/12 Digital Rights Ireland and Seitlinger and Others [2014] ECLI:EU:C:2014:238.
} 
ruling. ${ }^{77}$ In its Opinion, the Committee ${ }^{78}$ discussed the judgment by the CJEU in the Digital Rights Ireland case at length when reviewing the Government Bill (No. 221/2013) for the Information Society Code to the extent that the bill included provisions on data retention. Although the Constitutional Law Committee did not take the view that the judgment of the CJEU would prevent the adoption of new domestic legislation on mandatory data retention, the Committee nonetheless required some significant specifications to the proposal so as to achieve compliance with the Finnish Constitution and the EU Charter of Fundamental Rights, as seen in the light of the CJEU's judgment. The following points are worthy of elaboration for the present purposes:

1. The Constitutional Law Committee took the view that the EU Charter of Fundamental Rights, as interpreted by the CJEU in Digital Rights Ireland, still applies in this area despite the invalidity of the Data Retention Directive. Hence, the Finnish legislator was bound to take the Charter into account alongside the Constitution even though the Data Retention Directive was invalid ex tunc. The Committee apparently took the applicability of the Charter for granted since its opinion does not include any specific reasoning as to why the Charter still applies despite the invalidity of the Data Retention Directive ex tunc.

2. The Committee required the removal of all explicit references in the proposed legislation to the Data Retention Directive. It also demanded some other modifications to the bill, so as to comply with the requirements stemming from the right to privacy and the protection of personal data under Sect. 10 of the Finnish Constitution and the EU Charter, essentially requiring that data be retained only when strictly necessary for investigation, detection and prosecution in relation to a serious crime.

3. The Committee noted that its own well-established doctrine regarding the constitutional protection of 'metadata' (information about parties and about messages being sent and delivered between them) should be revised. Earlier, the constitutional doctrine had been that the processing of metadata was invariably seen as falling within such 'peripheral areas' of privacy and data protection where relatively wide-ranging limitations were permissible because the legislator was understood to enjoy a wide margin of discretion. Conversely, the intensity of constitutional review by the Committee of legislative provisions involving the processing of metadata had been 'low'. Now, however, the Committee took the view that the distinction between the content of electronic communications and such metadata as location data and traffic data could no longer be treated as a determining factor for the assessment of the level of fundamental rights intrusions. As a combination of various forms of metadata

\footnotetext{
77 Opinion 18/2014 of the Constitutional Law Committee.

78 The Constitutional Law Committee submitted its Opinion to the Transport and Communications Committee of Parliament which also discussed at length the provisions on data retention, including the judgment by the CJEU. Also, the Administration Committee (Opinion of 9/2014) gave its Opinion on the bill, including observations on data retention.
} 
can reveal a lot of confidential and sensitive personal information, constitutional attention should also be given to the assessment of the details of a particular situation, i.e. what types of metadata are at issue and what is their combined effect upon the right to privacy and data protection.

4. The Committee concluded that the proposed legislation did not include the flaws that jointly triggered the invalidity of the Data Retention Directive in the CJEU's judgment.

5. The Information Society Code with its provisions on mandatory data retention entered into force on 1 January 2015. According to the revised Sect. 157 of the Information Society Code, telecommunications companies, which are to be specified by a decision of the Ministry of the Interior (sisäministeriö), must retain location and traffic data as follows: (1) 12 months for data from a mobile network-based telephone or SMS-service; (2) 6 months for data from an internet-based telephone service, and (3) 9 months for data from an internet connection service. The retained data may only be used in the investigation and prosecution of the serious crimes stipulated in Chap. 10 Sect. 6(2) of the Coercive Measures Act (Pakkokeinolaki, Act No. 806/2011).

Hence, the period of retention is limited to 12 months at the most, and only data necessary for the purpose of preventing or investigating relatively serious crimes can be retained. Finnish law also seeks to make at least some distinctions between the categories of data on the basis of their possible usefulness for the purposes of the prevention, detection or prosecution of serious crimes.

Also, authorisation by a court is invariably necessary for each request for access to retained data, i.e. access is always dependent on a prior review carried out by a court, as required by the CJEU. Furthermore, unlike in the Directive, Finnish law includes relatively strict conditions on access to and exchange of retained data, including by specifying the national authorities that may be granted access to data to be retained. Finally, Finnish law provides for safeguards relating to the security and protection of data retained by private providers of electronic communications.

In conclusion, Finnish law seems to meet at least several of the requirements set out by the CJEU for mandatory data retention quite well although there is certainly room for arguing that the scope of application of retention should still be more limited in order to curtail the legislative framework on mandatory data retention to what is 'strictly necessary' as the CJEU required in its judgment.

Finally, it deserves emphasis that the judgment by the CJEU exemplifies how the case law of the EU Court of Justice can make a positive contribution to the evolution of domestic constitutional law in the area of fundamental rights protection. Indeed, the impact of EU membership on the domestic system for the protection of fundamental and human rights has often been positive, rather than harmful, in the context of several constitutional rights in Finland. Examples of the positive effects of EU membership abound, but the most noteworthy are perhaps those positive effects of EU membership that pertain to the constitutional protection of non-discrimination and equality. 


\subsection{Unpublished Or Secret Legislation}

2.5.1 In Finland, the constitutionality of unpublished or secret measures has not been raised as an issue. However, it may be added that generally the Constitution prohibits the existence of any 'secret' or 'unpublished' legislation. To begin with, Sect. 79 of the Constitution, entitled 'Publication and entry into force of Acts', explicitly requires that the Government shall 'without delay' publish an Act in the Statutes of Finland after signature by the President of the Republic (Sect. 2). Moreover, subsection 4 of the same provision unequivocally requires that all Acts 'are enacted and published in Finnish and Swedish' that enjoy the status of 'national languages of Finland' in accordance with Sect. 17(1), of the Constitution. ${ }^{79}$ Hence, it can be said that the validity of the law does not only depend on its publication per se but on its enactment and publication in both Finnish and Swedish. Finally, it also follows from the rule of law principle and the permissible limitations test for interferences with constitutional rights that each and every piece of legislation must be accessible and published, especially insofar as that legislation includes provisions on the exercise of public powers or the rights and obligations of individuals or other private parties.

\subsection{Rights and General Principles of Law in the Context of Market Regulation: Property Rights, Legal Certainty, Non-retroactivity and Proportionality}

2.6.1 In Finland, EU law has not directly affected the standard of protection of constitutional rights in the area of property rights. However, it can be noted on a general level that, as with the ECHR, EU law has contributed to a general inclination towards a model of constitutional reasoning in which general principles, inductive reasoning, precedents and case law make up the methods and body of both human rights law and rights constitutionalism. Namely, the traditional Finnish approach was characterised by a very formal, rule-focused reasoning that basically reflected the idea that the legislature has the competence to define the actual content of constitutional rights and that judicial powers must be exercised in this pre-legislated and judicially self-restrained framework. However, both international human rights law and EU law have emerged as one of the major reasons underpinning the transformation in the Finnish constitutional and human rights culture in

\footnotetext{
${ }^{79}$ Aside from providing explicitly that Finnish and Swedish are the national languages of Finland, Sect. 17(2), guarantees the right of everyone to use his or her own language, either Finnish or Swedish, before courts of law and other authorities, and to receive official documents in that language. Moreover, the public authorities are obliged to provide 'for the cultural and societal needs of the Finnish-speaking and Swedish-speaking populations of the country on an equal basis'.
} 
which reasoning based on such principles as legal certainty, non-retroactivity and proportionality have assumed greater significance in constitutional reasoning. ${ }^{80}$

\subsection{The ESM Treaty, Austerity Programmes and the Democratic, Rule-of-Law-Based State}

2.7.1 The constitutionality of euro crisis measures, among them the Treaty Establishing the European Stability Mechanism (ESM Treaty), has been discussed widely in Finland, both during the negotiation of the various crisis measures - be they international treaties or EU secondary law measures - as well as during the time of approving the measures at national level. ${ }^{81}$ Ultimately, Parliament has approved all the new agreements and brought them into force nationally, and has given the Government a mandate to approve the Union measures. The Constitutional Law Committee has taken a rather active role in evaluating these measures. $^{82}$

Already during negotiations, the draft ESM Treaty was addressed by Parliament under Sect. 96 specifically due to its effects on state finances. In the process of approving the Treaty, it was not considered to result in such a transfer of competence that would have to be considered significant (Sects. 94(2) and 95(2), of the Constitution). The Treaty was accepted in Parliament and brought into force nationally in accordance with the ordinary legislative procedure pertaining to an Act of Parliament.

The drafts of the ESM Treaty were scrutinised ex ante by Parliament and its Constitutional Law Committee before the treaty was submitted to the Parliament for final approval. The Constitutional Law Committee had established that the treaty impinged upon the legislative and budgetary powers of Parliament and thus approval by the latter was required. In some matters the Committee considered unanimous decision making in the stability mechanisms to be a precondition for compatibility with Finnish sovereignty and the Constitution. In particular, the emergency decision making procedure and the scope of decision making by qualified majority in the ESM Board of Governors provoked constitutionality issues. In the ex ante review, it seemed that the financial liabilities of Finland could also be increased by a qualified majority decision of the Board of Governors above the maximum limit defined in the Treaty, even if Finland opposed such a decision. This possibility was considered to affect national sovereignty and the budgetary competence of the Finnish Parliament, and led to demands to specify the agreement in this respect. ${ }^{83}$ The Finnish constitutional demands were understood during the

\footnotetext{
${ }^{80}$ For these effects of European integration on the Finnish legal culture, see e.g. Ojanen 2009a.

${ }^{81}$ See for example Leino and Salminen 2013, and Tuori and Tuori 2014.

${ }^{82}$ See the numerous Opinions of the Committee listed in Leino and Salminen 2013.

${ }^{83}$ Opinions 25/2011, 22/2011, 1/2011 and 13/2012 of the Constitutional Law Committee.
} 
negotiations on the European level, and the unanimity requirement was introduced into the Treaty.

According to the previously adopted interpretation, when considering the Treaty, the Constitutional Law Committee assessed the amount of Finnish capital investment in the European Stability Mechanism (ESM) and the related risks against the so-called Constitution-based obligations of the state. ${ }^{84}$ It required that all the financial liabilities and investments in the various parallel mechanisms be calculated in order to get a clearer picture of the liabilities. In order to establish the applicable procedure for the approval and bringing into force of the Treaty, the Committee considered the total amount of public debt and the risks of the investment. In the ESM, the Finnish part of the paid-in capital (1.4 billion EUR) and on demand callable capital ( 11 billion EUR) was found to be extensive when compared for example with the annual state budget. The annual state budget is approximately 54 billion EUR (2015). The paid capital is under $1 \%$ of the annual GDP, and the maximum is about $5 \%$ of the GDP.

Of major importance for the evaluation of the state's current liabilities and whether these might possibly compromise the ability of the state to take responsibility for its constitutional duties was the interpretation that Parliament has the possibility to genuinely control and influence the Finnish member of the ESM Board of Governors, where for example decisions on the capital payments are made unanimously. Through these interpretations of its participation and information rights, Parliament is now involved in the functioning of the mechanisms. Parliament has based the requirement concerning its participation in national decision making on Sects. 96 and 97 of the Constitution. The Finnish Parliament has considered that, for example, decisions relating to the granting of loans are as to their nature and their financial implications considered to be so significant that they require the provision of relevant information by the Government prior to decision making within the ESM in order to safeguard the prerogatives of the Parliament. It has even required that these constitutional requirements for the participation of Parliament through the national representative be reflected in the decision making rules, arrangements and practices within the ESM. ${ }^{85}$

2.7.2 When the elements of the Banking Union were discussed for the first time in the Constitutional Law Committee of Parliament in the ex ante review of the proposals, the Committee took a rather dubious, perhaps even a somewhat suspicious position towards the competence of the Union, and some elements in the international treaty (Agreement on the transfer and mutualisation of contributions to the Single Resolution Fund) that were planned in this context were evaluated as to whether they possibly contained constitutionally problematic features. ${ }^{86}$ When it then later reviewed the national implementing legislation and the same legislation

\footnotetext{
${ }^{84}$ See Opinions 13/2012 and concerning the European Financial Security Facility and the Framework Agreement Opinion 5/2011 of the Constitutional Law Committee.

${ }^{85}$ Opinion 13/2012 of the Constitutional Law Committee.

${ }^{86}$ Opinion 28/2013 of the Constitutional Law Committee.
} 
package contained the approval of an international agreement between the Member States and its incorporation into national law, no such problems were raised. While the legislation was carefully evaluated, it was not, however, deemed to cause problems which would have affected the relevant procedure. The international agreement was approved as it was not considered to result in a transfer of competence that would need to be considered significant (Sects. 94(2) and 95(2) of the Constitution), and it was accepted in Parliament and brought into force nationally in accordance with the ordinary legislative procedure pertaining to an Act of Parliament. $^{87}$

2.7.3 Not applicable. Finland has not been subject to a bailout or austerity programme.

\subsection{Judicial Review of EU Measures: Access to Justice and the Standard of Review}

2.8.1 Up until now, Finnish courts have yet to request a preliminary ruling by the CJEU on the validity of an EU measure. The peculiarity of the lack of preliminary ruling requests to the CJEU on the validity of EU measures is emphasised by the fact that the number of cases involving the application of constitutional rights and human rights by the courts has proliferated significantly since the mid-1990s. Furthermore, there have been a number of the specific form of constitutional challenge to the implementation of EU legislation at the legislative phase, as was already noted in the context of the domestic implementation of the European Arrest Warrant Framework Decision.

It may be added in this context that the total number of references by Finnish courts for a preliminary ruling to the CJEU has remained low. As of the end of 2014, Finnish courts had made 91 references. ${ }^{88}$ Given that Finland joined the EU in 1995 , the total number of references is so low that it may evince some sort of judicial 'resistance' to or 'shunning' of EU law by the Finnish courts. ${ }^{89}$ However, Finnish courts have embraced such fundamental qualities of EU law as direct effect, indirect effect and primacy well, although the cases in which Finnish courts have given primacy to EU law over conflicting national law have remained relatively few in number. Instead, EU law predominantly enters Finnish courts in the form of questions concerning the effect of EU law on the interpretation of Finnish law (the indirect effect of EU law). This approach appears to be of particular importance in cases involving prima facie tension between EU law and national law. In such cases, Finnish courts try to interpret, to the extent possible, national law in harmony

\footnotetext{
${ }^{87}$ Opinion 25/2014 of the Constitutional Law Committee.

${ }^{88}$ It is also significant to note that the Supreme Administrative Court of Finland alone has made 45 references for a preliminary ruling by the CJEU.

${ }^{89}$ For the application of EU law in Finnish courts, see in more detail Ojanen 2009a, pp. 198-201.
} 
with EU law so as to avoid any open conflict. The traditional constitutional doctrine emphasising the subordination of the judiciary to the legislature probably explains the judicial predisposition towards indirect effect, as it involves a similar method as that traditionally endorsed by Finnish courts in situations involving the granting of judicial effect to constitutional and human rights.

Finally, it is to be noted that the primary authority of constitutional interpretation and review in Finland - the Constitutional Law Committee of Parliament - is not considered a court or tribunal that is entitled to make a request for a preliminary ruling by the CJEU. This significantly hampers ex ante review by the Committee of proposals for EU measures or their domestic implementing enactments for their compatibility with the Constitution and human rights treaties, including the EU Charter of Fundamental Rights, because such a review often requires a sufficient knowledge of the meaning of EU law. The inability of the Committee to make preliminary ruling references also means that the Committee cannot engage in the same kind of constitutional dialogue with the CJEU as the constitutional courts of other Member States of the EU increasingly tend to have.

2.8.2-2.8.4 It is now submitted that the standard of judicial review by the EU courts cannot, at least in general terms, be considered lower than that applied by Finnish courts. Quite the contrary perhaps: it is to be emphasised that the traditional Finnish position towards judicially protected rights was remarkably 'distrustful', and 'reserved' until the late 1980s. Although Finland has had a written constitution with a constitutional rights catalogue since 1919 and its human rights treaty ratification record can be considered excellent, constitutional and human rights and the judiciary have assumed a rather marginal significance on the Finnish scene of constitutionalism. Instead, the country's constitutional system has revolved around such premises as the law as a supreme expression of the people's will, as well as around ideas about democracy as majority rule. ${ }^{90}$ The fundamental principle of legislative supremacy was intensified by the statutory legal system, as well as by a positivist conception of law. ${ }^{91}$ Finally, there was a rigid doctrine prohibiting judicial review of legislation for its compatibility with the Constitution. ${ }^{92}$

Given these constitutional traditions, there was a lack of any genuine judicial review based on constitutional or human rights in Finland before the 1990s. Instead, the traditional approach was a general inclination towards the idea that the legislature has the competence to define the actual content of rights, and that judicial powers must be exercised in this pre-legislated and judicially self-restrained

\footnotetext{
${ }^{90}$ See Nergelius 2006.

${ }^{91}$ A difference can be detected between the Nordic countries in that while Scandinavian realism remains the mainstream philosophy in the other Nordic countries, Finland maintains a more traditional Kantian-Kelsenian normativist perspective of legal positivism. As a historical background to this, reference can be made to the successful legal positivist resistance by the Finnish legal and political elite to campaigns of Russification in the late 19th and early 20th century when Finland was still an autonomous Grand-Duchy within the Russian Empire (until 1917). See also Scheinin 2008.

${ }^{92}$ See especially Lavapuro et al. 2011.
} 
framework. Indeed, there was hardly any room in the Finnish traditional thinking for a 'strict' standard of judicial review.

It now goes almost without saying that EU membership, together with international human rights treaties with the ECHR at their apex, have propelled the strong tendency towards rights-based constitutionalism since the late 1980s, with the outcome that the overall constitutional setting today is characterised by the peculiar combination of ex ante review by the Constitutional Law Committee of Parliament and a less traditional but now important ex post review by the courts. ${ }^{93}$ While there may be some differences between the standard of review by the EU courts and domestic constitutional actors at the level of individual cases, it is submitted here that it is simply impossible to maintain that in general the domestic standard is higher than that applied by the EU courts - or vice versa.

As noted already above, the judgment of the CJEU in the Digital Rights Ireland case warranted the adoption of a new approach by the Constitutional Law Committee of Parliament, as the Committee acknowledged that a rigid distinction between 'content' and 'metadata' (information about the parties and about the messages being sent and delivered between them) can no longer be treated as a decisive and determining factor for the assessment of fundamental rights intrusions due to surveillance (see Sect. 2.4).

\subsection{Other Constitutional Rights and Principles}

2.9.1 In Finland, the Constitution unequivocally requires that legal provisions on the exercise of public power, as well as on the rights and obligations of individuals or other private parties, must be laid down by an Act of Parliament. This premise is indicated by a number of constitutional provisions, such as Sect. 80 and Sect. 95 of the Constitution. ${ }^{94}$ It follows that all directives and other EU measures that regulate the rights or duties of individuals and other private parties or that otherwise are of a 'legislative nature' must be implemented through an Act of Parliament.

Yet tension can be noted as regards the methods of implementation of EU legislation where the method of incorporation through an Act of Parliament in blanco has been used, instead of the method of transformation which is clearly the most appropriate for the purpose of taking the requirements stemming from constitutional rights and the Constitution in general into account appropriately, as this method entails enacting domestic legislation in harmony with the EU measure in

\footnotetext{
${ }^{93}$ Ojanen 2009a.

${ }^{94}$ Section $80(1)$ provides that " $[\mathrm{t}]$ he principles governing the rights and obligations of individuals and the other matters that under this Constitution are of a legislative nature shall be governed by Acts of Parliament'. Section 95(1), in turn, provides that ' $[\mathrm{t}]$ he provisions of treaties and other international obligations, in so far as they are of a legislative nature, are brought into force by an Act of Parliament.' Several constitutional provisions on constitutional rights also require that more detailed provisions on those rights be laid down by an Act of Parliament.
} 
question. The method of incorporation on the other hand simply entails a statement in an Act of Parliament that a certain EU measure is in force domestically. Hence, it invites problems insofar as 'the quality of law' is concerned (see also the discussion in Sect. 2.3.6). The same can be said about the third major method of implementation of EU measures - reference, i.e. special clauses in domestic legislative provisions which stipulate that a specified EU measure is to be taken into account in the application of the Act in question. The Constitutional Law Committee of Parliament has on several occasions emphasised that the method of transformation should be preferred in the domestic implementation of EU legislation, especially in cases in which EU legislation affects individual rights or imposes obligations on individuals, or entails interferences with fundamental and human rights.

\subsection{Common Constitutional Traditions}

2.10.1-2.10.2 While there has been some scholarly discussion about the possible significance of the Finnish constitutional traditions, including constitutional identity, within the European context, this topic has yet to figure at the level of domestic constitutional practice, as neither the Constitutional Law Committee of Parliament nor the Finnish courts have thus far articulated 'Finnish constitutional traditions' in their practice. ${ }^{95}$

However, it should be emphasised that the Constitutional Law Committee of Parliament could very well take advantage of arguments originating in domestic constitutional traditions, including domestic constitutional identity, when expressing its views on the constitutionality of proposals for EU measures under Sect. 96 of the Constitution. Similarly, Finnish courts could refer to the long-standing constitutional traditions or idiosyncratic elements of the 'Finnish constitutional identity' when requesting a preliminary ruling from the CJEU on the interpretation of EU law or the validity of EU legislation. This has simply yet to be done.

\subsection{Article 53 of the Charter and the Issue of Stricter Constitutional Standards}

2.11.1 As already noted, one of the concerns in Finland on the threshold of Finland's accession to the EU was that EU membership might erode the national standard of protection of fundamental rights. Hence, some solutions of the 1995 Fundamental Rights Reform can be seen as attempts to protect certain constitutional rights against opposite tendencies that EU membership might entail in the long run. ${ }^{96}$ In 2001, the Constitutional Law Committee also went so far as to say that the

\footnotetext{
95 See Salminen 2014.

96 See e.g. Ojanen 2007, p. 157.
} 
domestic implementation of EU law was not permitted to weaken the domestic standard of rights protection ${ }^{97}$ - a claim with readily obvious potential for conflict with the primacy of EU law over all conflicting domestic law, especially in light of the judgment by the CJEU in the Melloni case ${ }^{98}$.

To date, the Constitutional Law Committee has already issued a myriad of Opinions on either proposals for EU measures or domestic implementing enactments of regulations, directives and other EU instruments in light of the Constitution and human rights obligations binding on Finland. It is possible to identify the following major trends and patterns in the welter of details in these Opinions.

The first major observation to be made is that despite Finnish fears to the contrary, EU membership has not posed any significant threat to domestic fundamental rights. In a clear majority of situations, it has been possible to implement EU law without having to fall short of the appropriate observance of fundamental and human rights. In other words, the constitutional premise that the implementation of EU measures may not weaken the protection of fundamental rights has so far very seldom resulted in the following optimisation dilemma: an effort by the national legislature or some other state organ to ensure the observance of fundamental rights undermines the effective implementation and enforcement of EU law - or vice versa. Indeed, it deserves to be emphasised that EU membership has actually contributed to the protection of fundamental and human rights in Finland in the area of several rights. Perhaps most noteworthy are the positive effects of EU law on the principles of equality and non-discrimination, as well as fundamental environmental rights.

The second major observation is that even if there has occasionally been a prima facie tension between domestic fundamental rights and EU law, the practice of the Constitutional Law Committee suggests an attempt to blunt the edge of any open conflict between domestic fundamental rights and EU law in a variety of ways. To start with, the Committee has avoided the reality of any open conflict by interpreting EU measures in a manner designed to meet the requirements stemming from domestic fundamental rights. ${ }^{99}$ The imprecise and open-ended wording of EU measures has often eased this task. Moreover, the Committee has increasingly taken advantage of the premise that EU law itself generally ensures an effective protection of fundamental rights and, moreover, demands that all areas of the EU legal order must be interpreted in a manner sensitive to EU fundamental rights. ${ }^{100}$ Yet another reason for the lack of tension between domestic fundamental rights and EU law has been that the EU measures in question have often assumed the character of minimum standard measures, i.e. they have only established the lowest common denominator in their field of application. Consequently, it has not been contrary to

\footnotetext{
97 Opinion 25/2001 of the Constitutional Law Committee.

98 Case C-399/11 Melloni [2013] EU:C:2013:107.

99 Opinion 5/2001 of the Constitutional Law Committee.

100 See e.g. Opinion 5/2001 of the Constitutional Law Committee.
} 
EU law to grant more extensive protection to domestic fundamental rights under national law. ${ }^{101}$ Finally, EU acts have most often been directives or framework decisions, which usually allow a broader or stricter margin of discretion for the Member States in their implementation.

Thirdly, it can be noted that there are a few situations involving the implementation of EU law in which the observance of fundamental and human rights has compromised the 'maximal' implementation of EU law. Aside from the implementation of the European Arrest Warrant Framework Decision discussed above, reference can be made to the domestic implementation of the Council Framework Decision of 13 June 2002 on combating terrorism. ${ }^{102}$ However, these situations have clearly been very rare exceptions to the rule which is simply that EU membership has not brought about any significant erosion of the domestic protection of fundamental and human rights.

Finally, it should be noted that the whole domestic thinking about 'stricter constitutional standards' has proved to be more self-sufficient and self-satisfied Finnish thinking than something reflecting the reality of Finnish legal practice. In Finland, the meaning of rights and, accordingly, the standard of protection is still very much dependent on majoritarian notions of democracy, formal notions of legal certainly and other similar factors that combine to cause what can be called a 'minimalist approach' to constitutional and human rights. Although the ECHR and other human rights treaties should feature 'only' as a minimum standard of rights protection, both the Constitutional Law Committee and the Finnish courts are far too often satisfied with the standard of protection under the ECHR, as indicated by the existing case law of the ECtHR. Hence, the problem is not only 'a race to the bottom', i.e. to the lowest common denominator of rights protection, but also the disregard of other human rights treaties beyond the ECHR. ${ }^{103}$

\subsection{Democratic Debate on Constitutional Rights and Values}

2.12.1 In principle, the Finnish system of abstract ex ante constitutional review by the Constitutional Law Committee of Parliament provides a good framework for democratic - or, perhaps more to the point, parliamentary - debate on constitutional rights and values in the context of European integration. Up until now, however, the most significant democratic debates on constitutional rights and values or fundamental constitutional principles in general have not taken place within the context

\footnotetext{
${ }^{101}$ See e.g. Opinions 1/2001 and 11/2001 of the Constitutional Law Committee.

102 Council Framework Decision 2002/475/JHA of 13 June 2002 on combating terrorism, [2002] OJ L $164 / 3$.

${ }^{103}$ For a minimalist approach to constitutional and human rights, see especially Lavapuro et al. 2011, especially pp. 518-529.
} 
of the implementation of the EAW Framework Decision or the EU Data Retention Directive, although there has been some discussion and debate in Parliament and elsewhere in Finnish civil society on these two topics. Instead, the most noteworthy democratic debates have related to the constitutionality of various measures, programmes and other instruments pertaining to the so-called euro crisis. As was already noted above in Sect. 2.7, Finland and particularly its Constitutional Law Committee were actually the forerunners in calling attention to various constitutional questions pertaining to the ESM Treaty and other instruments, and already at the time when these instruments were still at their draft stages.

2.12.2-2.12.3 The authors of this report are of the view that if a certain EU measure has raised serious constitutional questions in a number of constitutional courts or with similar domestic constitutional actors, this might very well warrant the interim suspension of the application of such measure until its validity has been resolved. Similarly, it is at least thinkable that the unconstitutionality of a certain EU measure might feature as a defensive argument in infringement proceedings against a Member State, although the admissibility of this argument would eventually be up to the CJEU to decide in light of the EU legal order as a whole, including the EU Charter of Fundamental Rights.

\subsection{Experts' Analysis on the Protection of Constitutional Rights in EU Law}

2.13.1 The Experts cannot share the concern about an overall reduction in the standard of protection of constitutional rights and the rule of law in the context of EU law. A reference is made here to what has been observed about the effects of EU membership on the domestic system for the protection of constitutional rights and human rights throughout Part 2 of the report. However, this is not to deny that there have been some situations in which EU law has fallen below the domestic standard of protection. Moreover, the implementation of EU law has sometimes compromised the 'quality of law' which is one important dimension of the rule of law principle and fundamental and human rights protection.

Overall, therefore, the reduction of the domestic standard of rights protection and the rule of law principle by EU membership can be described as 'low' and 'limited'.

\section{Constitutional Issues in Global Governance}

\subsection{Constitutional Rules on International Organisations and the Ratification of Treaties}

3.1.1 The Constitution of Finland does not include any specific rules on international organisations beyond the EU and the general internationalisation clause, 
'Finland participates in international co-operation for the protection of peace and human rights and for the development of society' (Sect. 1(3)), as was already noted in Part 1 of this report.

3.1.2 For the background of the above-mentioned internationalisation clause, see Sects. 1.2.1 and 1.5.3.

\subsection{The Position of International Law in National Law}

3.2.1-3.2.2 As a matter of domestic constitutional law, the hierarchical status of the domestic incorporating Act of an international treaty determines the form and rank of the treaty provisions in the domestic legal order. As international treaties are brought into force domestically either through an Act of Parliament in blanco or through a similar government decree, it follows that the formal status of an international treaty assumes either the hierarchical rank of an Act of Parliament or a government decree. Moreover, the Constitutional Law Committee of Parliament has emphasised that the method of incorporation warrants the direct application of international treaties by the domestic courts and authorities. ${ }^{104}$

Insofar as the issue of ratification and implementation of treaties under international law, including the founding treaties of the EU, are concerned, in the Constitution of Finland, the relationship between Finnish law and international law has traditionally been understood as representing the dualist approach. Therefore, no international treaty can be part of Finnish law solely by virtue of its acceptance by Parliament. A distinct domestic legal enactment is also required for the purpose of making any particular international treaty part of the Finnish legal order. The 'dualist approach' is clearly indicated by Sects. 94 and 95 of the Constitution, which distinguish between 'Acceptance of international obligations and their denouncement' (Sect. 94) and 'Bringing into force of international obligations' (Sect. 95). However, as the predominant method of implementing international treaties in Finland is incorporation either through an Act of Parliament in blanco or through a similar government decree, the Finnish constitutional position towards international treaties represents dualism formally, but monism in practice.

It also deserves emphasis that international human rights treaties are a special case among international treaties in the domestic constitutional setting, ${ }^{105}$ as they assume what might be called semi-constitutional status. This feature is the outcome of the following four factors: (i) several constitutional provisions explicitly refer to both domestic constitutional rights and international human rights; (ii) the method of incorporation warrants their direct applicability by domestic courts and authorities; (iii) courts and authorities are obliged to interpret all domestic law, including

${ }^{104}$ See e.g. Opinion 2/1990 of the Constitutional Law Committee on the direct applicability of the ECHR due to the method of incorporation.

105 See Scheinin 1996, pp. 259-260. 
constitutional provisions on constitutional rights in a 'human rights-oriented' way; and (iv) the status of international human rights treaties as a minimum standard of domestic rights protection.

\subsection{Democratic Control}

3.3.1 In the Finnish system, Parliament is involved in the negotiation, acceptance and incorporation of treaties according to the same sets of rules as already explained in Part 1. As to the acceptance and incorporation of treaties, Sect. 94 and Sect. 95 of the Constitution apply. Although the Government has a major role in international affairs alongside the President, depending on the content of the treaty, Parliament has competence to accept and incorporate treaties. In the negotiation phase, Sect. 97 is relevant from the point of view of Parliament and democratic control. It should be noted, however, that Sect. 96 provides Parliament better means for controlling the Government's actions. Thus, in many cases it is important to discuss whether the international treaty in question, despite having the form of an international treaty, is de facto an EU affair. In practice, the division between Sects. 96 and 97 has become indistinct.

The European Stability Mechanism provides an excellent example of this. This applies to scrutiny beyond its ratification as well. Through the interpretations of participation and information rights, Parliament is involved in the functioning of the mechanism.

3.3.2 Only EU accession has been subject to a referendum. Sometimes, in political discussions, NATO accession is mentioned as one possible case for a referendum. Typically, the legitimacy of this kind of decision is mentioned as the rationale for a referendum. As already mentioned above, the Constitution allows for such referendums, but they are not constitutionally required.

\subsection{Judicial Review}

3.4.1 See Sects. 2.1 and 2.8 .

\subsection{The Social Welfare Dimension of the Constitution}

3.5.1 The Constitution of Finland includes several rights which are a basis for the social welfare dimension of the Constitution, and international human rights treaties also have a role in this aspect. 
Nevertheless, the privatisation of public services for example has been rather quick and most certainly affects the welfare dimension of the Constitution. Delegation of public powers has occurred at all levels of the administration, especially at the local level. Section 124 of the Constitution of Finland provides the specific constitutional context for the limitations on privatisation. According to Sect. 124,

[a] public administrative task may be delegated to others than public authorities only by an Act or by virtue of an Act, if this is necessary for the appropriate performance of the task and if basic rights and liberties, legal remedies and other requirements of good governance are not endangered. However, a task involving significant exercise of public powers can only be delegated to public authorities.

In Finland, global governance has not been a major or direct cause of the possible weakening of the welfare state or the erosion of the social elements of the society, rather this has been caused by domestic politics which are of course highly dependent on European and international tendencies.

\subsection{Constitutional Rights and Values in Selected Areas of Global Governance}

3.6.1 In Finland, there has been some domestic discussion and debate about the possible negative impact of the investment protection regime under the Transatlantic Trade and Investment Partnership (TTIP), which is currently being negotiated between the European Union and the United States. In essence, the worry has been that the planned investment protection regime could transfer powers from the EU, domestic legislators and other public authorities to an arbitration body with the outcome that this could inhibit Finland from adopting stricter legislative measures in such areas as environmental and consumer protection, social policy and employment. Also, the democratic legitimacy of the planned investment protection regime has come into question. ${ }^{106}$

\footnotetext{
${ }^{106}$ See also Opinion 1/2014 of the Foreign Affairs Committee and Opinion 1/2014 of the Grand Committee where attention is called to the need to secure that the planned investment protection regime would not prevent Finland from adopting new legislation in the areas of consumer protection, environmental protection and employment. The distinguished Finnish legal scholar Professor Martti Koskenniemi has also cautioned in several interviews and public speeches that the free trade pact could allow companies investing in Finland to launch legal action due to restrictions laid out in Finnish legislation. See e.g. (2013, December 15). Professor: Finland's legislative power may be in jeopardy. Helsinki Times. http://www.helsinkitimes.fi/finland/finland-news/ domestic/8717-professor-finland-s-legislative-power-may-be-in.
} 


\section{References}

Albi A. (2005) EU Enlargement and the Constitutions of Central and Eastern Europe. Cambridge University Press, Cambridge.

Claes M. (2005) Constitutionalizing Europe at its Source: The 'European Clauses' in the National Constitutions: Evolution and Typology. Yearbook of European Law, pp. 81-125.

Hallberg P., Karapuu, H., Ojanen, T., Scheinin, M., Tuori, K., Viljanen, V.-P. (eds.) (2011) Perusoikeudet (Fundamental Rights). Werner Söderström Lakitieto Oy, Helsinki.

Heinonen T. (2012) Konstitutionaalinen konflikti Suomessa (Constitutional conflict in Finland). In: Heinonen T., Lavapuro J. (eds.) Oikeuskulttuurin eurooppalaistuminen. (The Europeanization of Legal Culture). Suomalainen Lakimiesyhdistys, Helsinki, pp. 201-239.

Lavapuro, J., Ojanen T., Scheinin M. (2011) Rights-Based Constitutionalism in Finland and the Development of Pluralist Constitutional Review. ICON 9:505-531.

Leino P., Salminen J. (2013) The Euro Crisis and Its Constitutional Consequences for Finland: Is There Room for National Politics in EU Decision-Making? EuConst 9:451-479.

Mutanen A. (2015) Towards a Pluralistic Constitutional Understanding of State Sovereignty in the European Union? The Concept, Regulation and Constitutional Practice of Sovereignty in Finland and Certain Other EU Member States. University of Helsinki, Helsinki.

Nergelius J. (2006) The Nordic States and Continental Europe: A Two-Fold Story. In: Nergelius J. (ed.) Nordic and Other European Constitutional Traditions. Martinus Nijhoff, The Hague, pp. 3-4.

Ojanen T. (2003) Euroopan unioni ja kotimainen perusoikeusjärjestelmä (The European Union and the domestic system for the protection of fundamental rights). Lakimies 101(7-8):1150 et seq.

Ojanen T. (2004) The Impact of EU Membership in Finnish Constitutional Law. EPL 10:531-564.

Ojanen T. (2006) The European Arrest Warrant in Finland. Taking Fundamental and Human Rights Seriously. In: Guild E. (ed.) Constitutional challenges to the European Arrest Warrant. Wolf Legal Publishers, Nijmegen, pp. 89-100.

Ojanen, T. (2007) The Europeanization of Finnish Law. In: Luif P. (ed.) Österreich, Schweden, Finnland. Zehn Jahre Mitgliedschaft in der Europäischen Union. Böhlau Vienna, pp. 145-178.

Ojanen T. (2009a) From Constitutional Periphery toward the Center - Transformations of Judicial Review in Finland. Nordisk Tidsskrift for Menneskerettigheter (Nordic Journal of Human Rights) 27:194-207.

Ojanen T. (2009b) The European Arrest Warrant in the Midnight Sun. The Implementation and Application of the EAW in Finland. In: Guild E., Marin L. (eds.) Still Not Resolved? Constitutional Issues of the European Arrest Warrant. Wolf Legal Publishers, Nijmegen, pp. $143-156$.

Ojanen T. (2009c) Perus- ja ihmisoikeudet EU-säädösten toimeenpanolakien säätämisessä (Fundamental and human rights in the domestic implementation of EU measures). In: Kanninen H., Koskinen H., Rosas A., Sakslin M., Tuori K. (eds.) Puhuri käy: muuttuva suomalainen ja eurooppalainen valtiosääntömme (Blowing in the wind: the changing Finnish and European constitution). Edita Publishing, Helsinki, pp. 129-174.

Ojanen T. (2011) EU-oikeuden perusteita (The Foundations of EU-law). Edita Publishing, Helsinki.

Ojanen T. (2013) Constitutional amendment in Finland. In: Contiades X. (ed.) Engineering Constitutional Change, A Comparative Perspective on Europe, Canada and the USA. Routledge, Abingdon, pp. 93-113.

Salminen J. (2004) Täysivaltaisuuden rajoituksesta täysivaltaisuuden käyttöön - Havaintoja valtiosääntöisen täysivaltaisuuskäsityksen muutoksesta (From restriction to use of sovereignty: Observations on the change of the sovereignty concept). Lakimies 102(7-8):1318-1339.

Salminen J. (2009) Toimivallan siirto Euroopan unionille (Transfer of Powers to the European Union). In Juhlajulkaisu Mikael Hidén 1939-7/12-2009. Suomalainen Lakimiesyhdistys, Helsinki, pp. 269-283. 
Salminen J. (2010a) Manifestations of the European Union Membership in the Constitution of Finland in the European Context. Europarättslig tidskrift 13(3):509-527.

Salminen J. (2010b) Revideringen av grundlagen - beredningen av nödvändiga ändringar i Finlands grundlag (Amending the Constitution - Preparing the Necessary Amendments of the Constitution of Finland). Förvaltningsrättslig tidskrift 73(2):161-177.

Salminen J. (2014) Den konstitutionella identiteten, förändringen och Finland (Constitutional identity, change and Finland). Retfaerd 37(3):41-63.

Salminen J. (2015) Yhä läheisempään liittoon? Tutkielmia valtiosäännön integraationormin sisällöstä ja vaikutuksista (Towards an ever closer union? The contents and effects of the constitutional integration clause). Turun yliopisto, Turku.

Scheinin M. (1996) Finland. In: Scheinin M. (ed.) International Human Rights Norms in the Nordic and Baltic Countries. Martinus Nijhoff Publishers, Leiden, pp. 257-280.

Scheinin M. (2001) Protection of Economic, Social and Cultural Rights in Finland - A Rights-Based Variant of the Welfare State? In: Scheinin M. (ed.) Constitutionalism and the Welfare State. Nordic Perspectives. Nordic Council of Ministers, Copenhagen, pp. 245-285.

Scheinin M. (2002) Constitutional Law and Human Rights. In: Pöyhönen J. (ed.) An Introduction to Finnish Law. Kauppakaari, Helsinki, pp. 31-57.

Scheinin M. (2008) Constitutionalism and Approaches to Rights in the Nordic Countries. In: Nergelius J. (ed.) Constitutionalism: New Challenges - European Law from a Nordic Perspective. Martinus Nijhoff, Leiden, pp. 135-153.

Suksi M. (2011) Finland. In: Oliver D., Fusaro C. (eds.) How Constitutions Change: A Comparative Study. Hart Publishing, Oxford, pp. 87-114.

Tuori K., Tuori K. (2014) The Eurozone Crisis: A Constitutional Analysis. Cambridge University Press, Cambridge.

Viljanen V.-P. (1996) Perusoikeusuudistus ja kansainväliset ihmisoikeussopimukset (The reform of fundamental rights and international human rights treaties). Lakimies 94(5-6): 792-806.

Viljanen V.-P. (1999) Poikkeuslakien välttämisen periaate (The avoidance of exceptive enactments principle). Lakimies 97(6-7):961-962.

Viljanen, V.-P. (2001) Perusoikeuksien rajoitusedellytykset (Restriction of Basic Rights). Werner Söderström Lakitieto Oy, Helsinki.

Viljanen V.-P. (2003) Eurooppalaistuminen valtioelinten välisissä suhteissa (The Europeanisation of the domestic separation of powers). Lakimies 101(7-8): 1169-1183.

Viljanen V.-P. (2009) Perustuslain muuttamisesta ja muuttamatta jättämisestä (To amend a Constitution - or not to amend). In: Kanninen H., Koskinen H., Rosas A., Sakslin M., Tuori K. (eds.) Puhuri käy: muuttuva suomalainen ja eurooppalainen valtiosääntömme (Blowing in the wind: the changing Finnish and European constitution). Edita Publishing, Helsinki, pp. 57-88.

Open Access This chapter is licensed under the terms of the Creative Commons Attribution 4.0 International License (http://creativecommons.org/licenses/by/4.0/), which permits use, sharing, adaptation, distribution and reproduction in any medium or format, as long as you give appropriate credit to the original author(s) and the source, provide a link to the Creative Commons license and indicate if changes were made.

The images or other third party material in this chapter are included in the chapter's Creative Commons license, unless indicated otherwise in a credit line to the material. If material is not included in the chapter's Creative Commons license and your intended use is not permitted by statutory regulation or exceeds the permitted use, you will need to obtain permission directly from the copyright holder. 